\title{
Petrographic and biomarker analysis of xylite-rich coal from the Kolubara and Kostolac lignite basins (Pannonian Basin, Serbia)
}

\author{
NATAŠA ĐOKOVIĆ ${ }^{1}$, DANICA MITROVIĆ ${ }^{1}$, DRAGANA ŽIVOTIĆ ${ }^{2}$, ACHIM BECHTEL $^{3}$, \\ REINHARD F. SACHSENHOFER ${ }^{3}$ and KSENIJA STOJANOVIĆ ${ }^{4,1, \otimes}$ \\ ${ }^{1}$ University of Belgrade, Innovation Centre of the Faculty of Chemistry, Studentski trg 12-16, 11000 Belgrade, Serbia; \\ ndjokovicpost@gmail.com; danicamitrovic87@gmail.com \\ ${ }^{2}$ University of Belgrade, Faculty of Mining and Geology, Đušina 7, 11000 Belgrade, Serbia; dragana.zivotic@rgf.bg.ac.rs \\ ${ }^{3}$ Montanuniversität Leoben, Department of Applied Geosciences and Geophysics, Peter-Tunner-Str. 5, A-8700 Leoben, Austria; \\ achim.bechtel@unileoben.ac.at; reinhard.sachsenhofer@unileoben.ac.at \\ ${ }^{4}$ University of Belgrade, Faculty of Chemistry, Studentski trg 12-16, 11000 Belgrade, Serbia; $₫$ ksenija@chem.bg.ac.rs
}

(Manuscript received March 29, 2017; accepted in revised form December 12, 2017)

\begin{abstract}
The maceral and biomarker characteristics of 4 sublithotypes of xylite-rich coal (SXCs), pale yellow, dark yellow, brown and black, originating from the Kolubara and Kostolac lignite basins were determined. Based on these results, differences in sources and changes of organic matter $(\mathrm{OM})$ resulting in formation of 4 SXCs were established. Conifers (particularly Cupressaceae, Taxodiaceae and Pinacea) had a significant impact on the precursor OM of all SXCs. The contribution of gymnosperm vs. angiosperm vegetation decreased in order pale yellow SXC $>$ dark yellow SXC $>$ brown SXC>black SXC. The distribution of non-hopanoid triterpenoids indicates that change of SXC colour from yellow to black is associated with reduced input of angiosperm plants from the Betulacea family. Differences in hopane distribution, bitumen content, proportion of short-chain $n$-alkanes and degree of aromatization of di- and triterpenoids of pale yellow SXC are controlled by microbial communities which took part in the diagenetic alteration of OM. The content of total huminites increased from black to pale yellow SXC, whereas contents of total liptinite and inertinite macerals showed the opposite trend. SXCs differ according to textinite/ulminite ratio, which sharply decreased from pale yellow to black SXC, reflecting increase in gelification of woody tissue. Regarding the composition of liptinite macerals, the SXCs mostly differ according to resinite/liptodetrinite and resinite/suberinite ratios, which are higher in yellow than in brown and black SXC. This result along with values of TOC/N ratio and Carbon Preference Index indicate that the contribution of well preserved woody material, including lignin tissue vs. the impact of epicuticular waxes decreased from yellow to black SXC.
\end{abstract}

Keywords: Kolubara, Kostolac, lignite, sublithotypes of xylite-rich coal, macerals, biomarkers.

\section{Introduction}

Lignite is one of the main energy resources in central and southeast Europe. According to Reichl et al. (2016), Poland, Turkey, Greece, Czech Republic, Serbia, Bulgaria, Bosnia and Herzegovina, Romania and Hungary are placed among the 15 greatest producers. Serbia produced about $30 \mathrm{Mt}$ of lignite in 2014. The main lignite deposits in Serbia are located in the Upper Miocene Kolubara and Kostolac basins (Fig. 1), and in the Kovin deposit (Jelenković et al. 2008).

According to their macropetrographic composition, structure and texture, lignites can be classified into several lithotypes. The lithotype classification system for lignite (soft brown coal) proposed by the International Committee for Coal and Organic Petrology (ICCP 1993; Taylor et al. 1998) distinguishes: xylite-rich coal, matrix coal, charcoal-rich coal and mineral-rich coal. Lithotype varieties (sublithotypes) can be differentiated by their degree of gelification and colour (Jacob 1961; Ercegovac 1989; Kwiecińska \& Wagner 1997). Composition and characteristics of lignite which directly influence its applicability depend on sources of organic matter $(\mathrm{OM})$ and the degree of transformation during peat genesis and diagenesis. For establishing the precursors of lignite $\mathrm{OM}$ and its digenetic alteration, micropetrographic (maceral) analysis and biomarker composition are most useful.

Although numerous petrographic and biomarker studies have been performed on whole lignite samples (e.g., Bechtel et. al. 2007; Zdravkov et al. 2011; Životić et al. 2014; Mitrović et al. 2016), to the best of our knowledge detailed investigation of lignite sublithotypes has not been performed. Xyliterich coal is widespread and can form layers, several tens of metres thick. This lithotype is abundant in Upper Miocene deposits of Serbia, Bulgaria and Greece. Moreover, individual sublithotypes of xylite-rich coal (SXC) influence lignite utilization. In this study, four different SXCs (pale yellow, dark yellow, brown, black) were isolated from lignites of the Kolubara and Kostolac, the most important basins in Serbia. The main objective was to establish the sources and to reveal the differences of precursor organic matter which resulted in the formation of four different SXCs. For that purpose maceral 
compositions and biomarker distributions were investigated in detail.

\section{Geological setting}

The most important Serbian lignite basins belong to the Pannonian Basin System and were formed in shallow lacustrine, delta plain and fluvial environments during the Miocene. Upper Miocene ("Pontian") coalbearing series from the Kolubara and Kostolac lignite basins (PontianMessinian-ICS; Fig. 2) were formed in freshwater environments. In both basins, the coal seams are associated with sandy-clayey sediments.

The Kolubara Basin is located about $60 \mathrm{~km} \mathrm{~S}-\mathrm{SW}$ of Belgrade (442' $\left.21^{\prime \prime} \mathrm{N}, 20^{\circ} 12^{\prime} 18^{\prime \prime} \mathrm{E}\right)$, and covers an area of almost $600 \mathrm{~km}^{2}$, while the Kostolac Basin is located about $90 \mathrm{~km} \mathrm{E}$ of Belgrade (444' $\left.41^{\prime \prime} \mathrm{N}, 21^{\circ} 14^{\prime} 45^{\prime \prime} \mathrm{E}\right)$ and covers an area of $145 \mathrm{~km}^{2}$ (Fig. 1). Annually, the Kolubara Basin produces about $30 \mathrm{Mt}$ of lignite (http:// www.rbkolubara.rs/index.php? option=com_content\&view= article\&id=83\&Itemid=189). The Kostolac Basin produces 9-12 Mt (http://www.te-ko.rs).

The basement of the Kolubara Basin consists of Devonian and Carboniferous schists, gneisses, slates and sandstones, Mesozoic mica-rich sandstones, shales, dolomitic limestones, limestones and flysch, and Tertiary phenoandesites, phenodacites, quartz-latite, ignimbrites and quartz-latite tuffs (Ercegovac \& Pulejković 1991; Životić et al. 2014). The Upper Miocene ("Pontian") coalbearing sediments, 250 to $320 \mathrm{~m}$ thick, host three coal seams (Kezović 2011; Fig. 2): Seam III (Lower Coal Seam), Seam II (Main Coal Seam) and Seam I (Upper Coal Seam) with average thicknesses of $7 \mathrm{~m}, 25 \mathrm{~m}$ and $11 \mathrm{~m}$, respectively. The coal-bearing sediments dip at low angles towards the northern and central parts of the basin. On the southern border of the SE part of the basin, coalbearing sediments are characterized
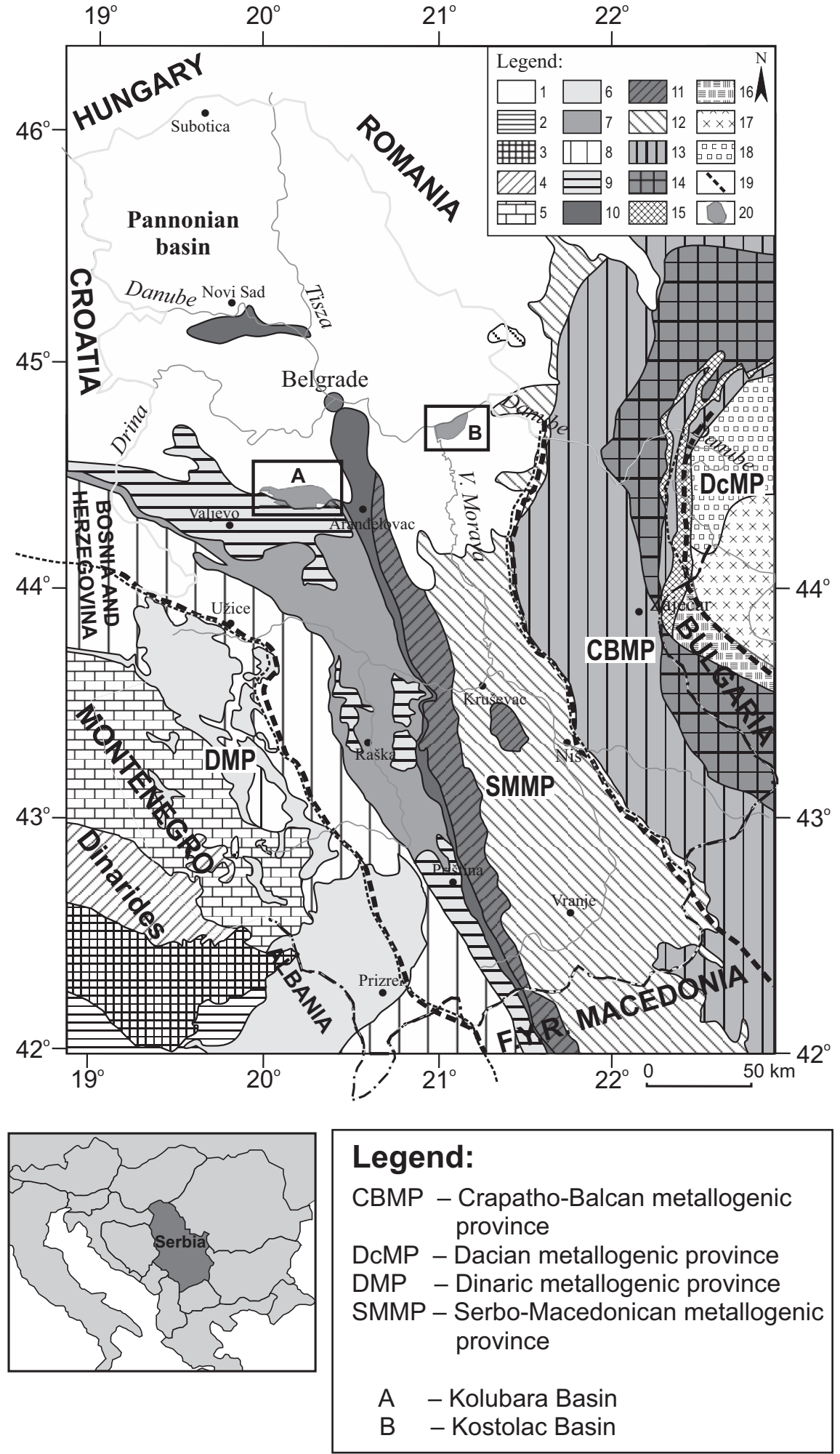

Fig. 1. Main geotectonic and metallogenic units of Serbia (modified after Dimitrijević 2000; Schmid et al. 2008).

1 - Pannonian Basin; 2 - Budva-Cukali Zone; 3 - High Karst Unit; 4 - Pre-Karst and Bosnian Flysch Unit; 5 - East Bosnian-Durmitor Thrust Sheet; 6 - Dinaric Ophiolitic Belt; 7 - Western Vardar Ophioliic Unit; 8 - Drina-Ivanjica Thrust Sheet; 9 - Jadar-Kopaonik Thrust Sheet; 10 - Sava Zone; 11 - Eastern Vardar Ophiolitic Unit; 12 - Serbo-Macedonian Unit; 13 - Getic Unit; 14 - Danubian Nappes; 15 - Ceahlau-Severin Unit; 16 - Central Balkan and Prebalkan Units; 17 - Moesian Platform; 18 - External Moesian Foredeep; 19 - Boundary of metallogenic units; 20 - Locations of the Kolubara (A) and Kostolac (B) basins. 
by a synform, due to the intense post-sedimentary faulting, causing occasional erosion of coal in the SE part of the basin.

The basement of the Kostolac Basin consists of Devonian crystalline rocks overlain by Neogene sediments (Stojanović et al. 2012; Fig. 2). The Upper Miocene ("Pontian") coalbearing series of the Kostolac Basin hosts five coal seams, which are termed from bottom to top seams III, II-a, II, I-a, and I. The average thickness of Seam III is $19.4 \mathrm{~m}$, while it is $1.4 \mathrm{~m}$ for IIa, $4.1 \mathrm{~m}$ for II, 1.5 for Ia and $13.9 \mathrm{~m}$ for coal seam I (Životić et al. 2014). The coal-bearing sediments generally dip toward NW at low angles of $5-15^{\circ}$.

\section{Methods}

Two representative feed lignite samples (mass $\sim 5 \mathrm{~kg}$ of each) from the Kolubara and the Kostolac basins were collected from the pre-boiler mills of thermal power plants "Nikola Tesla" and "Kostolac B", respectively.

For lithotype analyses, the lignite samples were crushed to a maximum particle size of $3 \mathrm{~mm}$ and dried at room temperature. Lignites were manually separated into matrix, char coal, mineral-rich coal, dopplerite coal (a black very brittle type of coal made of humic gel; Taylor et al. 1998; Feller et al. 2010;

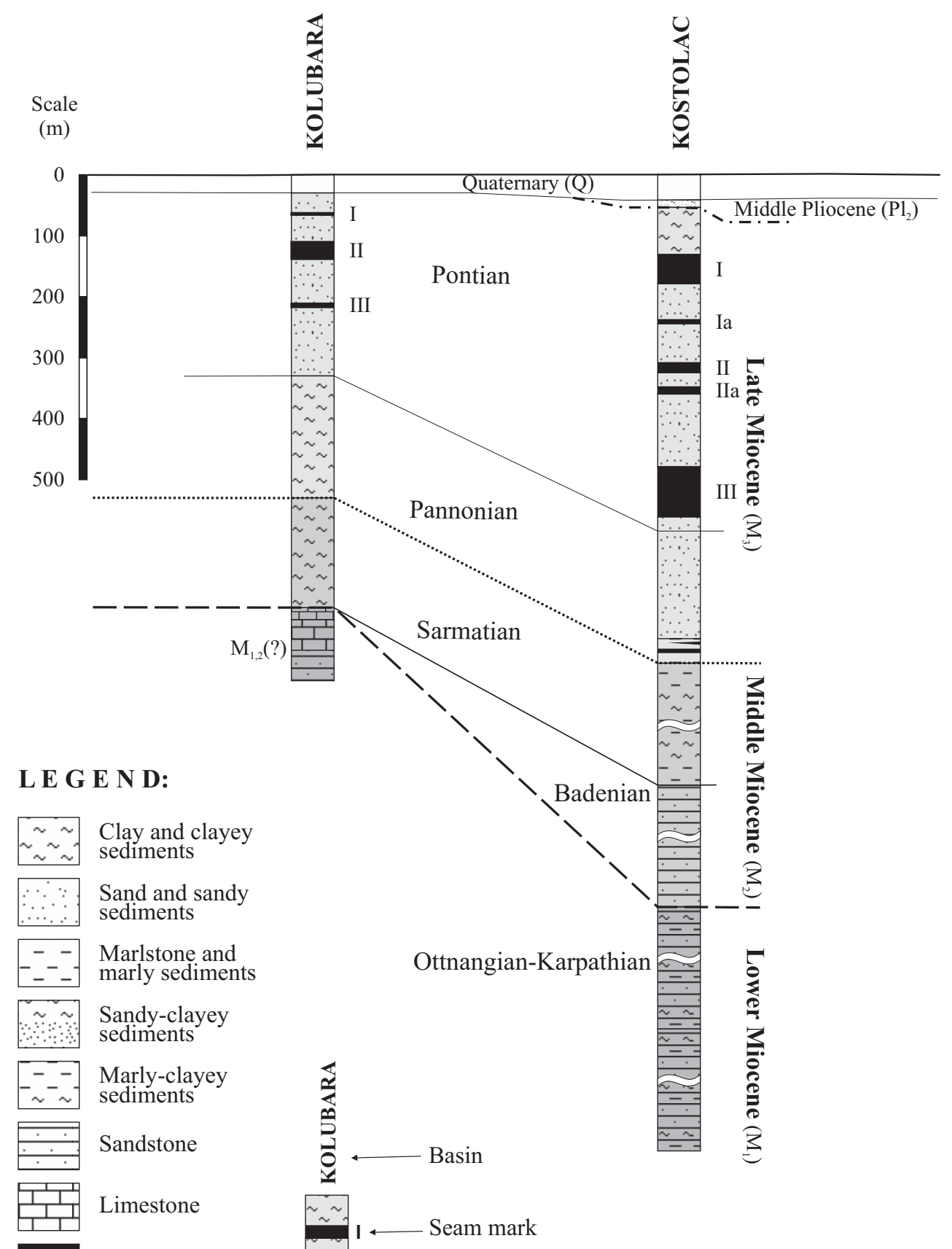

Fig. 2. Schematic lithostratigraphic column of the Neogene from the Kolubara and Kostolac. 
Suárez-Ruiz et al. 2012), four different sublithotypes of xylitic coal (pale yellow, dark yellow, brown and black; Fig. 3) and mineral matter under the stereo microscope. Four sublithotypes of xylite-rich coal (SXCs; pale yellow, dark yellow, brown and black), from each basin, in total 8 samples, were further analysed in detail (Table 1). The macroscopic description of the coal lithotypes followed the nomenclature proposed by ICCP (ICCP 1993; Taylor et al. 1998). The xylite description used in this study follows the terminology developed by Jacob (1961) and modified by Ercegovac (1989).

For maceral analyses, separated SXCs were crushed to a maximum particle size of $1 \mathrm{~mm}$, mounted in epoxy resin and polished. The maceral analyses were performed on a Leitz DMLP microscope in monochromatic and UV light illumination on 500 points (ISO 7404-3, 2009). The maceral description used in this study follows the terminology developed by the International Committee for Coal and Organic Petrology for huminite (Sykorova et al. 2005), liptinite (Pickel et al. 2017) and inertinite (ICCP 2001) nomenclature.

Elemental analysis was performed to determine the contents of sulphur, nitrogen and total organic carbon (TOC). TOC content was determined after removal of carbonates with diluted hydrochloric acid $(1: 3, \mathrm{v}: \mathrm{v})$. The measurements were done using a Vario EL III, CHNS/O Elemental Analyser, Elementar Analysensysteme GmbH.

For the determination of the molecular composition of OM approximately $5 \mathrm{~g}$ of pulverized material $(<150 \mu \mathrm{m})$ was extracted with dichloromethane for $1 \mathrm{~h}$ at $75^{\circ} \mathrm{C}$ and pressure of 50 bar using a Dionex ASE 200 accelerated solvent extractor. Solvent was evaporated and extracts (bitumens) were concentrated by a Zymark Turbo Vap 500 device. Extracts were dissolved in a mixture of $n$-hexane:dichloromethane (80:1, v:v) and asphaltenes were subsequently separated by centrifugation. The $n$-hexane-soluble organic compounds (maltenes) were separated into saturated hydrocarbons, aromatic hydrocarbons and NSO-fraction (polar fraction, which contains nitrogen, sulphur, and oxygen compounds) using a Kohnen-Willsch MPLC (medium pressure liquid chromatography) instrument (Radke et al. 1980).

The saturated and aromatic hydrocarbon fractions were analysed by gas chromatography-mass spectrometry (GC-MS). A gas chromatograph equipped with a $30 \mathrm{~m}$ DB-5MS fused silica capillary column (i.d. $0.25 \mathrm{~mm}$; $0.25 \mu \mathrm{m}$ film thickness) coupled to a Thermo Scientific ISQ quadrupole mass spectrometer was used. The oven temperature was programmed from $70{ }^{\circ} \mathrm{C}$ to $300{ }^{\circ} \mathrm{C}$ at a rate of $4{ }^{\circ} \mathrm{C} / \mathrm{min}$ followed by an isothermal period of 15 min. Helium was used as carrier gas. The sample was injected in the splitless mode with the injector temperature at $275^{\circ} \mathrm{C}$. The mass spectrometer was operated in the electron impact (EI) mode over a scan range from $\mathrm{m} / \mathrm{z} 50$ to $\mathrm{m} / \mathrm{z} 650$ ( $0.7 \mathrm{~s}$ total scan time). Identification of individual compounds was accomplished based on comparison of the mass spectra with published data (Wakeham et al. 1980; Philp 1985; Stout 1992; Killops et al. 1995, 2003; Otto \& Simoneit 2002; Peters et al. 2005). Data were processed with an Xcalibur data system. Absolute concentrations of individual compounds were calculated using peak areas in relation to those of internal standards (deuterated $n$-tetracosane for saturated hydrocarbons and 1,1'-binaphthyl for aromatic hydrocarbons). The concentrations were normalized against $T O C$ contents.

\section{Results and discussion}

\section{Bulk organic geochemical parameters}

TOC contents (Table 1) are generally similar (55-61\%) with the exception of pale yellow SXC from the Kolubara Basin, which shows a lower amount (48\%). Sulphur content does not show any relationship with the SXC, but is lower in Kolubara samples $(<0.9 \%)$ than in Kostolac samples $(1.1-2.3 \%)$ (Table 1). Since lignites in both basins were formed in freshwater environments, higher sulphur content in
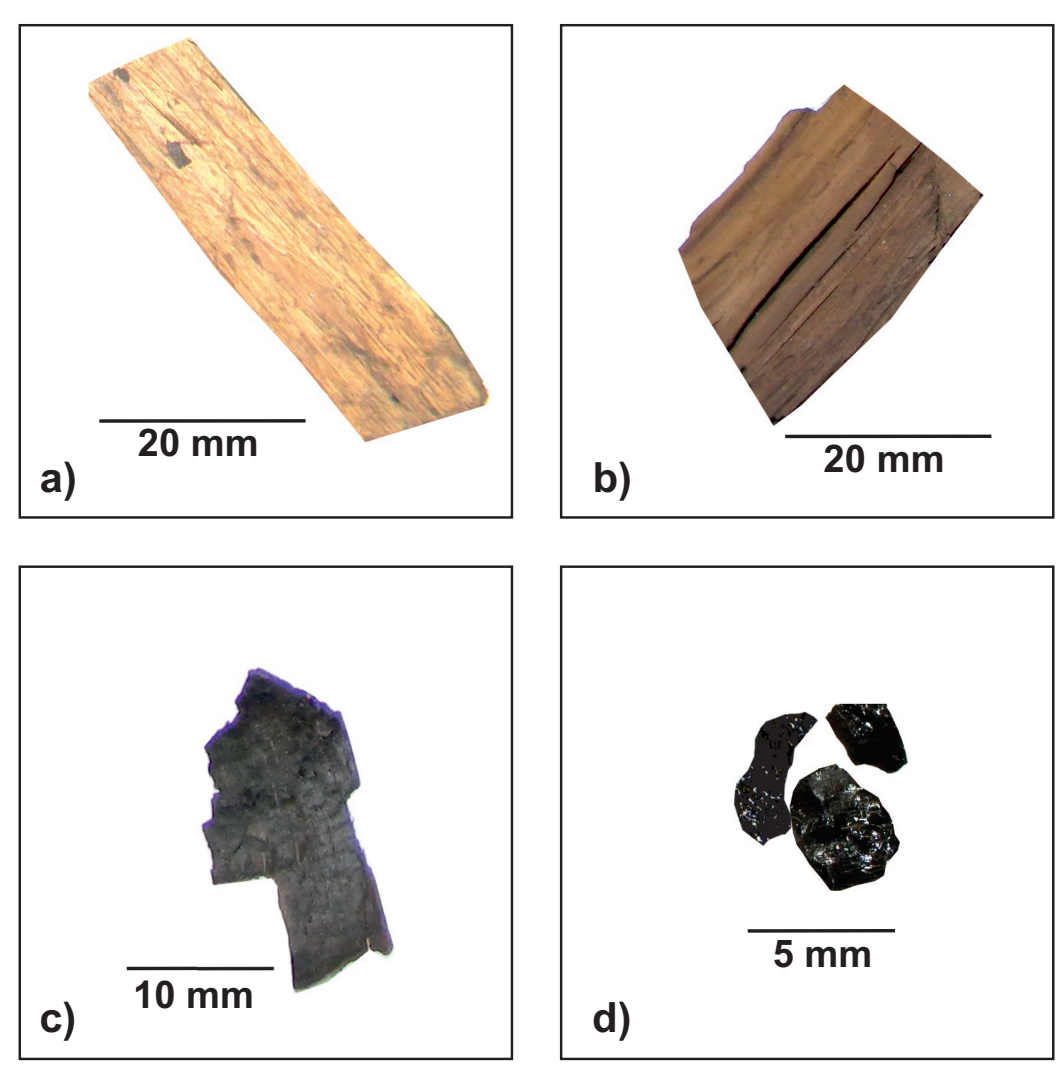

Fig. 3. Photomicrographs of different SXCs isolated from the Kolubara and Kostolac lignites under the stereo microscope: $\mathbf{a}$ - Pale yellow SXC; b - Dark yellow SXC; c-Brown SXC; d- Black SXC. 
the Kostolac samples could be attributed to calcium-rich surface waters derived from the surrounding calcareous country rock, which caused increase of the $\mathrm{pH}$ (Markic \& Sachsenhofer 1997). Therefore the obtained result suggests slightly more alkaline conditions during peatification in the Kostolac than in the Kolubara Basin. The TOC/N ratios exceed 60 in all samples (Table 1), which is typical for terrestrial flora (Meyers \& Ishiwatari 1993). The highest ratios in both basins were detected in yellow (pale yellow and dark yellow) SXCs, which may be considered as an indication of terrestrial plants with domination of lignin tissue (Edress 2007).

The extract yield of the soluble organic matter (bitumen) is variable and ranges from 15.31 to $273.24 \mathrm{mg} / \mathrm{g}$ TOC (Table 1). It has been attributed to the variable proportion of biogenic and diagenetic compounds. The content of bitumen decreases in the following order: pale yellow $\mathrm{SXC}>$ dark yellow $\mathrm{SXC}>$ brown SXC $>$ black SXC in both basins suggesting certain differences in the source material, followed by less pronounced condensation into macromolecular structures and/or more intense microbial degradation of precursor biomolecules in yellow SXCs.

The contents of saturated and aromatic hydrocarbons are low, while the contents of asphaltenes and polar NSO fraction (containing nitrogen, sulphur and oxygen compounds) are high (Table 1), as expected for immature terrestrial organic material.

\section{Molecular composition of the organic matter}

\section{General characteristics}

All investigated samples are dominated by diterpenoids, followed by non-hopanoid triterpenoids and $n$-alkanes
(Figs. 4-7; Table 2). Pale yellow and dark yellow SXCs from both basins and black SXC from Kostolac are characterized by higher content of non-hopanoid triterpenoids than $n$-alkanes, whereas brown SXCs from both basins and Kolubara black SXC displayed the opposite trend. Since distributions of $n$-alkanes (see Section $n$-Alkanes and isoprenoids) showed that these biomarkers mostly originated from epicuticular waxes, the obtained result may indicate lower contribution of waxes to yellow SXCs in comparison to brown and black SXCs. Other hydrocarbon constituents of bitumen are hopanoids, sesquiterpenoids, steroids and isoprenoids (Figs. 4-7; Table 2). Diterpenoids have the highest proportion in all samples. Proportion of diterpenoids decreased in order: pale yellow SXC $>$ dark yellow $\mathrm{SXC}>$ brown $\mathrm{SXC}>$ black $\mathrm{SXC}$, whereas proportions of all other biomarkers increased in the opposite trend, with the exception of sesquiterpenoids which showed a higher proportion in brown than in black SXCs from both basins (Table 2). Hopanoids are more abundant than sesquiterpenoids in Kolubara samples, whereas SXCs from Kostolac demonstrate the opposite trend, with the exception of Kostolac black SXC, which contains slightly a higher amount of hopanoids in comparison to sesquiterpenoids (Table 2). This result generally indicates more intense microbial activity during peatification in the Kolubara Basin.

Diterpenoids, non-hopanoid triterpenoids and sesquiterpenoids

Total diterpenoids (sum of diterepenoids in saturated and aromatic fractions) represent the most abundant hydrocarbons in bitumen, indicating a significant contribution of conifers (gymnosperms) to the precursor OM. The presence of a considerable amount of non-hopanoid triterpenoids implies that

Table 1: Short description of SXCs and values of bulk organic geochemical parameters.

\begin{tabular}{|c|c|c|c|c|c|c|c|c|c|c|c|}
\hline SXC & Short description & $\mathrm{W}^{\text {an }}(\%)$ & TOC (\%) & S (\%) & N (\%) & TOC/N* & $\begin{array}{r}\text { Extract yield } \\
(\mathrm{mg} / \mathrm{g} \text { TOC) } \\
\end{array}$ & $\begin{array}{r}\text { Saturated } \\
\text { HC (\%) } \\
\end{array}$ & $\begin{array}{r}\text { Aromatic } \\
\text { HC (\%) } \\
\end{array}$ & $\begin{array}{r}\text { NSO } \\
(\%) \\
\end{array}$ & $\begin{array}{l}\text { Asp } \\
(\%)\end{array}$ \\
\hline \multicolumn{12}{|l|}{ Kolubara } \\
\hline Pale yellow & $\begin{array}{l}\text { Pale yellow, with well- } \\
\text { preserved wood tissue }\end{array}$ & 5.79 & 48.08 & 0.46 & 0.20 & 280.47 & 110.81 & 4.34 & 1.12 & 33.12 & 61.42 \\
\hline Dark yellow & $\begin{array}{l}\text { Dark yellow, with well- } \\
\text { preserved wood tissue }\end{array}$ & 7.82 & 57.72 & 0.39 & 0.39 & 172.67 & 62.49 & 3.43 & 0.91 & 49.00 & 46.66 \\
\hline Brown & $\begin{array}{l}\text { Light to dark brown, } \\
\text { with preserved wood } \\
\text { tissue }\end{array}$ & 8.20 & 56.88 & 0.53 & 0.52 & 127.62 & 49.88 & 1.83 & 0.75 & 71.20 & 26.22 \\
\hline Black & $\begin{array}{l}\text { Black, with visible } \\
\text { wood structure }\end{array}$ & 9.10 & 56.03 & 0.89 & 0.68 & 96.13 & 22.12 & 3.71 & 1.84 & 48.17 & 46.28 \\
\hline \multicolumn{12}{|l|}{ Kostolac } \\
\hline Pale yellow & $\begin{array}{l}\text { Pale yellow, with well- } \\
\text { preserved wood tissue }\end{array}$ & 7.66 & 60.85 & 2.30 & 0.57 & 124.55 & 273.24 & 3.43 & 0.50 & 73.84 & 22.23 \\
\hline Dark yellow & $\begin{array}{l}\text { Dark yellow, with well- } \\
\text { preserved wood tissue }\end{array}$ & 8.35 & 59.78 & 1.09 & 0.52 & 134.12 & 46.57 & 6.71 & 1.23 & 45.63 & 46.43 \\
\hline Brown & $\begin{array}{l}\text { Light to dark brown, } \\
\text { with preserved wood } \\
\text { tissue }\end{array}$ & 9.22 & 55.14 & 1.36 & 0.78 & 82.47 & 30.26 & 4.53 & 1.71 & 55.95 & 37.81 \\
\hline Black & $\begin{array}{l}\text { Black, with visible } \\
\text { wood structure }\end{array}$ & 10.29 & 59.82 & 1.65 & 0.96 & 72.70 & 15.31 & 5.12 & 2.13 & 50.00 & 42.75 \\
\hline
\end{tabular}

$W^{a n}$ - Analytical moisture content; $T O C$ - Total organic carbon content, dry basis; $S$ - Total sulphur content, dry basis; $N$ - Total nitrogen content, dry basis; * - Molar ratio; $H C$ - Hydrocarbons; NSO — polar fraction, which contains nitrogen, sulphur and oxygen compounds; Asp — Asphaltenes. 
angiosperms also contributed to coal formation (Figs. 4-7; Table 2). The ratio of total diterpenoids to total non-hopanoid terpenoids, $D i /(D i+T r i)$ (Bechtel et al. 2002, 2003a), which is indicative for the contribution of gymnosperm vs. angiosperm vegetation decreased in the order pale yellow $\mathrm{SXC}>$ dark yellow SXC $>$ brown SXC $>$ black SXC (Table 2). In all samples sesquiterpenoids were present in lower amounts than di- and triterpenoids (Figs. 4-7; Table 2).

Distributions of individual diterpenoids in saturated fractions are similar. The $16 \alpha(\mathrm{H})$-phyllocladane and pimarane are dominant by far. Other diterpenoid type constituents of saturated fraction are isopimaradiene, isonorpimarane, norpimarane, dihydrorimuene, isophyllocladene and $16 \beta(\mathrm{H})-$ phyllocladane (Figs. 4, 5). A high amount of $16 \alpha(\mathrm{H})-$ phyllocladane indicates a peat-forming vegetation built up by Taxodiaceae, Podocarpaceae, Cupressaceae, Araucariaceae and/or Phyllocladaceae, while high abundance of pimarane suggests Pinaceae, Taxodiaceae and/or Cupressaceae (Otto et al. 1997; Otto \& Wilde 2001; Stefanova et al. 2005a).

Distributions of individual diterpenoids in the aromatic fractions of all samples are relatively similar (Figs. 6, 7). The aromatic diterpenoids consist of norabieta- $6,8,11$, 13-tetraenes, norabieta-8,11,13-trienes, dehydroabietane, simonellite, retene, sempervirane, totarane, hibaene and 2-methylretene. Simonellite and dehydroabietane are predominant compounds in Kolubara samples, while simonellite prevailed in all samples from Kostolac (Figs. 6, 7). Almost all of the aromatic diterpenoids are non-specific conifer markers, because they are diagenetic products of a great variety of abietane-type precursors that are common constituents of all conifers except Phyllocladaceae (Otto et al. 1997; Otto \& Wilde 2001; Stefanova et al. 2005a). However, the presence of totarane and hibaene in the aromatic fraction of all samples (Figs. 6, 7) clearly indicates the contribution of Cupressaceae, Taxodiaceae, Podocarpaceae and/or Araucariaceae to the precursor biomass (Otto \& Wilde 2001). This is consistent with the implications obtained by the analysis of saturated biomarkers.

The ratio of saturated to aromatic diterpenoids is higher than 1 in all samples (Table 2) suggesting a low degree of aromatization of these biomarkers. The ratio generally decreased from yellow to brown and black SXCs, suggesting more intense diagenetic aromatization of ditepenoids in later.

Yellow SXCs from the Kolubara Basin have higher absolute content of non-hopanoid triterpenoids than brown and black SXCx, whereas the opposite trend is observed for the Kostolac samples (Table 2). However, the proportion of non-hopanoid triterpenoids in both basins clearly increased in the order pale yellow $\mathrm{SXC}<$ dark yellow $\mathrm{SXC}<$ brown $\mathrm{SXC}<$ black $\mathrm{SXC}$ (Table 2).

Although, non-hopanoid triterpenoid biomarkers are indicative for angiosperm input, they are not useful for a precise determination of the precursor plant family, with the exception of lupane derivatives which are generally more abundant in the Betulacea family (Hayek et al. 1989; Regnery et al. 2013).
The non-hopanoid triterpenoids are present in low amounts in the saturated fractions of all SXCs and consist exclusively of des-A degraded compounds (des-A-olean-13(18)-ene, des-A-olean-12-ene and des-A-lupane; Figs. 4, 5).

On the other hand, non-hopanoid triterpenoids predominate in the aromatic fraction of all SXCs from the Kolubara Basin and after diterpenoids represent the most abundant aromatic biomarkers in Kostolac samples (Figs. 6, 7; Table 2). Considerably higher abundance of aromatized in comparison to saturated angiosperm triterpenoids, resulting in the ratio of saturated to aromatic non-hopanoid triteprenoids notably $<1$ in all samples (Table 2), which indicates intense aromatization of triterpenoids during diagenesis. The same observation was also reported by Kalkreuth et al. (1998) and Nakamura et al. (2010), which showed that aliphatic angiosperm-derived triterpenoids are more easily altered to aromatic derivatives than gymnosperm-derived diterpenoids, resulting in the selective loss of analogous aliphatic compounds.

The distributions of individual non-hopanoid terpenoids in the aromatic fractions of all samples are relatively similar (Figs. 6, 7). The following tetra- and pentacyclic aromatic triterpenoids occur in the aromatic fractions: ring-A-monoaromatic triterpenoids (24,25-dinoroleana-1,3,5(10),12-tetraene, 24,25-dinorursa-1,3,5(10),12-tetraene, 24,25-dinorlupa1,3,5(10)-triene, 24,25-dinorlupapentaene, trisnorlupatriene, trisnoroleanatetraene, trisnorlupapentaene), tetramethyloctahydrochrysenes, trimethyltetrahydrochrysenes, tetramethyloctahydropicenes and trimethyltetrahydropicenes. 24,25-Dinoroleana-1,3,5(10),12-tetraene and 24,25-dinorlupa-1,3,5(10)triene are predominant compounds in all SXCs (Figs. 6, 7). Pentacyclic triterpenoids are more abundant than tetracyclic chrysene derivatives in all samples. This result indicates that the main pathway of aromatization was progressive aromatization (Stout 1992).

Oleanane and lupane derivatives predominated over nonhopanoid triterpenoids with ursane skeleton in all SXCs (Table 2). The ratio of olenane- vs. lupane derivatives increased from yellow to brown and black SXCs (Table 2). Since lupane derivatives mostly originated from Betulacea family (Hayek et al. 1989; Regnery et al. 2013), the obtained result could suggest a higher contribution of this family to yellow SXCs.

In contrast to the ratio of saturated to aromatic diterpenoids which decreased from yellow to brown and black SXCs, the corresponding ratio based on non-hopanoid triterpenoids showed the opposite trend (Table 2). The obtained results suggest that brown and black SXCs are enriched in aromatic diterpenoids in comparison to yellow SXCs, whereas aromatization of non-hopanoid triterpenoids was more intense in yellow sublithotypes of xylite-rich coal. This observation may be attributed to differences in precursor $\mathrm{OM}$ and activity of different microbial communities. Moreover, degree of aromatization of non-hopanoid triterpenoids is higher in Kolubara than in Kostolac samples consistent with the already assumed more intense microbial activity in this basin.

In all the studied samples, sesquiterpenoids occur in relatively low quantities (Figs. 4-7). The absolute contents of ses- 


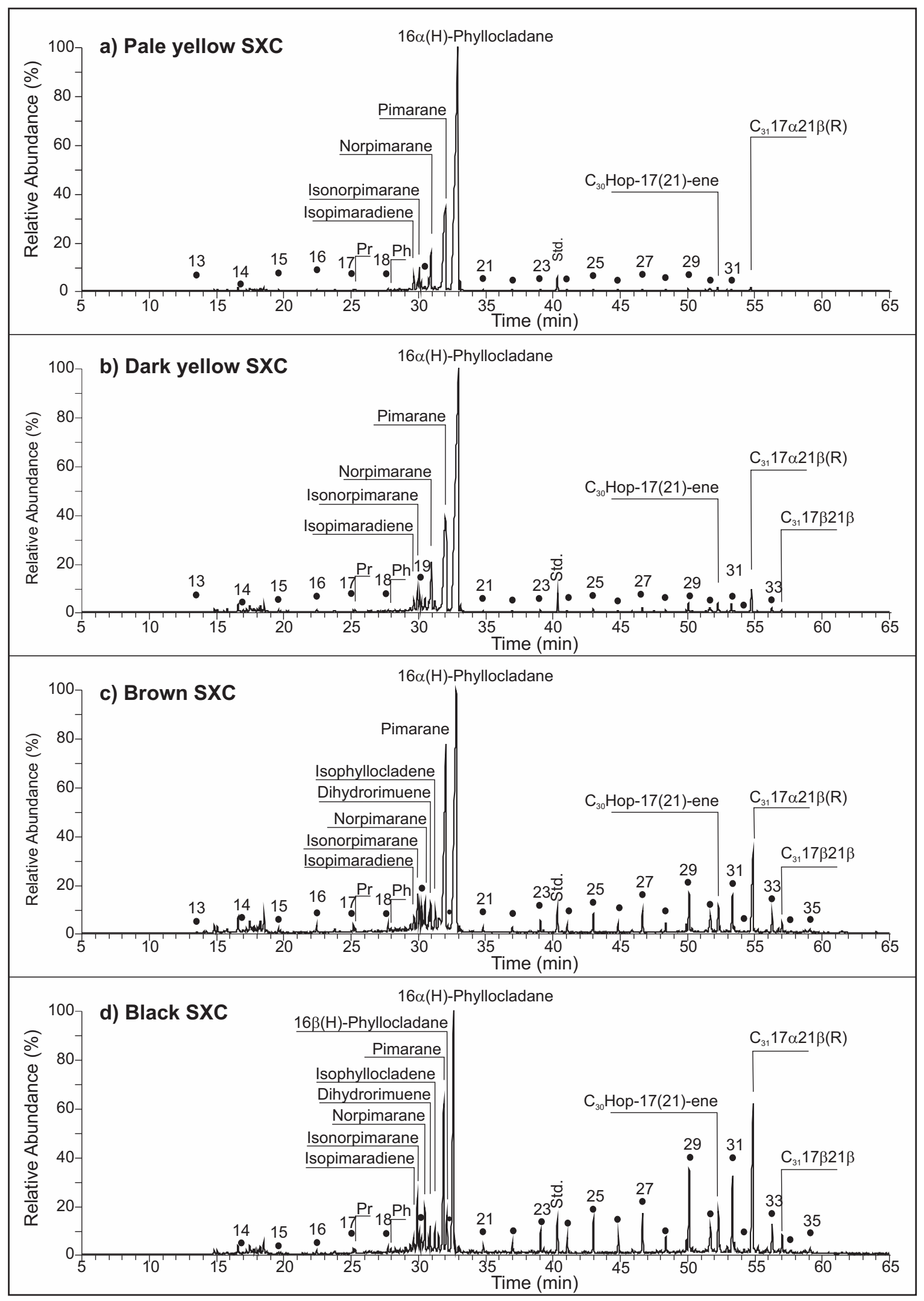

Fig. 4. TIC (Total Ion Chromatogram) of the saturated fraction of SXCs from the Kolubara Basin. $\bullet-n$-Alkanes are labelled according to their carbon number; $\mathrm{Pr}$ - Pristane; $\mathrm{Ph}$ - Phytane; Std. - Standard (deuterated $n$-tetracosane); $17 \alpha 21 \beta$ and $17 \beta 21 \beta$ designate configurations at $\mathrm{C}-17$ and $\mathrm{C}-21$ in hopanes, (R) designates configuration at C-22 in hopanes. 


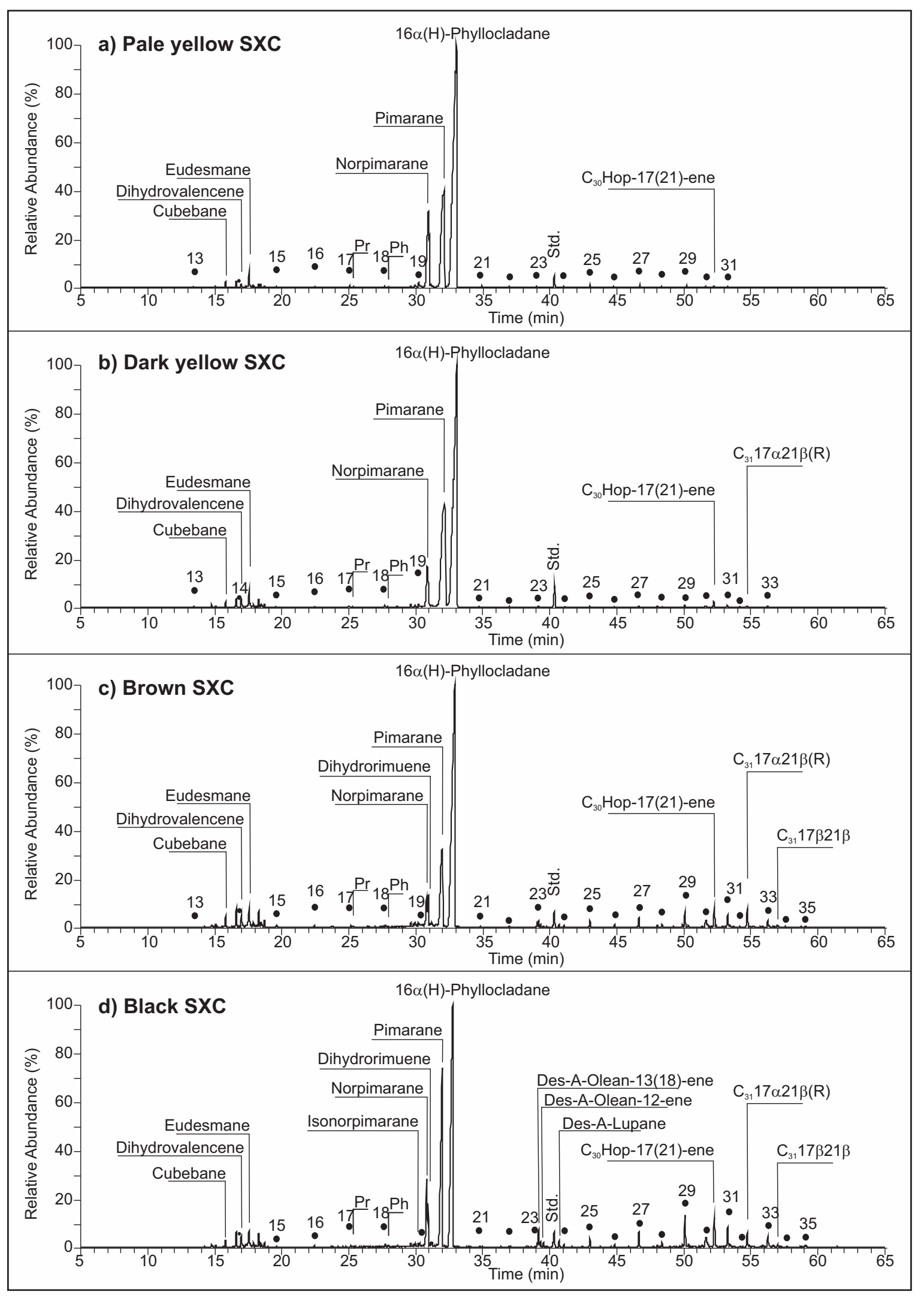

Fig. 5. TIC of the saturated fraction of SXCs from the Kostolac Basin. $-n$-Alkanes are labelled according to their carbon number; $\mathrm{Pr}$ - Pristane; $\mathrm{Ph}$ - Phytane; Std. - Standard (deuterated $n$-tetracosane); $17 \alpha 21 \beta$ and $17 \beta 21 \beta$ designate configurations at C-17 and C-21 in hopanes, (R) designates configuration at $\mathrm{C}-22$ in hopanes. 


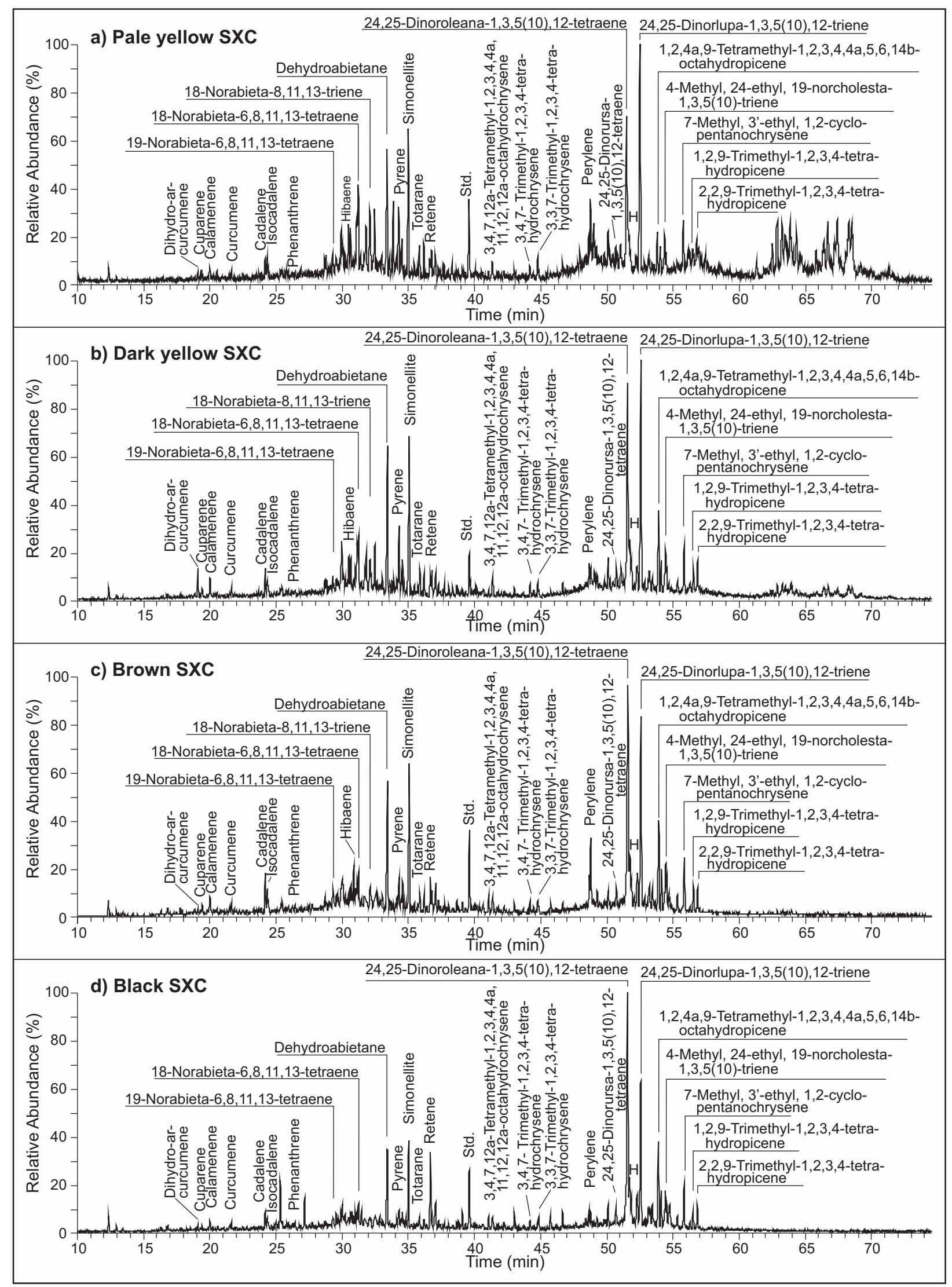

Fig. 6. TIC of the aromatic fraction of SXCs from the Kolubara Basin. Std. - Standard (1,1' binaphthyl); H - D-ring monoaromatic hopane. 


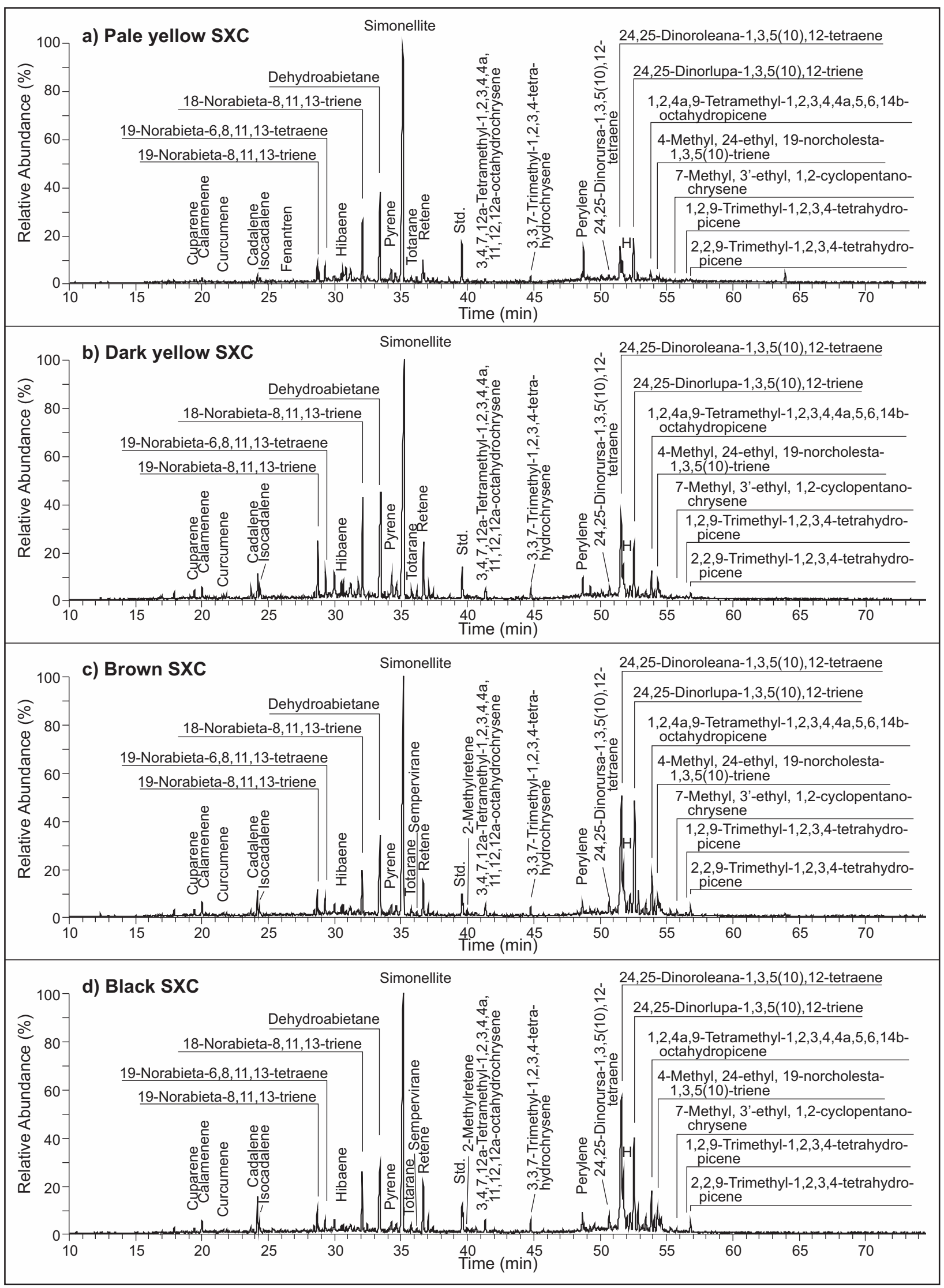

Fig. 7. TIC of the aromatic fraction of SXCs from the Kostolac Basin. Std — Standard (1,1' binaphthyl); H - D-ring monoaromatic hopane. 
Table 2: Absolute contents of biomarker classes, relative proportions of biomarker classes and values of biomarker parameters.

\begin{tabular}{|c|c|c|c|c|c|c|c|c|}
\hline \multirow{2}{*}{$\begin{array}{l}\text { Basin } \\
\text { SXC }\end{array}$} & \multicolumn{4}{|c|}{ Kolubara } & \multicolumn{4}{|c|}{ Kostolac } \\
\hline & Pale yellow & Dark yellow & Brown & Black & Pale yellow & Dark yellow & Brown & Black \\
\hline Sat $D i(\mu \mathrm{g} / \mathrm{g} T O C)$ & 3153.69 & 2237.88 & 322.09 & 113.31 & 8487.60 & 1733.02 & 866.87 & 350.28 \\
\hline Arom $D i(\mu \mathrm{g} / \mathrm{g} T O C)$ & 133.40 & 95.48 & 22.77 & 18.60 & 212.57 & 181.37 & 71.03 & 75.11 \\
\hline Total $D i(\mu \mathrm{g} / \mathrm{g} T O C)$ & 3287.09 & 2333.36 & 344.86 & 131.91 & 8700.17 & 1914.39 & 937.90 & 425.39 \\
\hline Sat Tri $(\mu \mathrm{g} / \mathrm{g} T O C)$ & 0.15 & 2.04 & 1.44 & 1.33 & 2.17 & 2.06 & 10.30 & 12.68 \\
\hline Arom Tri $(\mu \mathrm{g} / \mathrm{g}$ TOC $)$ & 126.93 & 123.39 & 41.65 & 49.00 & 50.86 & 54.82 & 50.10 & 62.98 \\
\hline Total Tri $(\mu \mathrm{g} / \mathrm{g} T O C)$ & 127.08 & 125.43 & 43.09 & 50.33 & 53.03 & 56.88 & 60.40 & 75.66 \\
\hline Sat Sesq $(\mu \mathrm{g} / \mathrm{g} T O C)$ & 37.91 & 17.27 & 22.26 & 10.02 & 46.33 & 20.96 & 59.18 & 20.68 \\
\hline Arom $\operatorname{Ses} q(\mu \mathrm{g} / \mathrm{g}$ TOC $)$ & 12.42 & 15.45 & 5.14 & 2.77 & 7.17 & 15.59 & 7.10 & 8.02 \\
\hline Total Sesq $(\mu \mathrm{g} / \mathrm{g}$ TOC) & 50.33 & 32.72 & 27.40 & 12.79 & 53.50 & 36.55 & 66.28 & 28.70 \\
\hline Sat hopanoids $(\mu \mathrm{g} / \mathrm{g} T O C)$ & 3.52 & 67.67 & 48.56 & 79.29 & 9.58 & 5.69 & 15.91 & 11.00 \\
\hline Arom hopanoids ( $\mu \mathrm{g} / \mathrm{g} T O C)$ & 8.11 & 7.44 & 2.79 & 3.59 & 11.15 & 8.78 & 10.57 & 13.13 \\
\hline Total hopanoids ( $\mu \mathrm{g} / \mathrm{g}$ TOC) & 11.63 & 75.11 & 51.35 & 82.88 & 20.73 & 14.47 & 26.48 & 24.13 \\
\hline Sat steroids $(\mu \mathrm{g} / \mathrm{g} T O C)$ & 1.11 & 1.14 & 2.84 & 3.03 & 2.84 & 0.62 & 7.40 & 6.88 \\
\hline Arom steroids ( $\mu \mathrm{g} / \mathrm{g}$ TOC) & 1.51 & 2.57 & 1.29 & 1.05 & 1.66 & 0.40 & 1.43 & 0.51 \\
\hline Total steroids $(\mu \mathrm{g} / \mathrm{g} T O C)$ & 2.62 & 3.71 & 4.13 & 4.08 & 4.50 & 1.02 & 8.83 & 7.39 \\
\hline Total $n$-alkanes $(\mu \mathrm{g} / \mathrm{g}$ TOC) & 80.15 & 86.78 & 78.20 & 93.54 & 43.20 & 19.60 & 75.05 & 51.07 \\
\hline Total isoprenoids ( $\mu \mathrm{g} / \mathrm{g} T O C)$ & 8.47 & 6.48 & 2.38 & 2.22 & 8.47 & 2.68 & 0.82 & 1.96 \\
\hline Proportion of total $D i(\%)$ & 92.14 & 87.60 & 62.54 & 34.92 & 98.00 & 93.67 & 79.69 & 69.37 \\
\hline Proportion of total Tri $(\%)$ & 3.56 & 4.71 & 7.81 & 13.32 & 0.60 & 2.78 & 5.13 & 12.34 \\
\hline Proportion of total Sesq $(\%)$ & 1.41 & 1.23 & 4.97 & 3.39 & 0.60 & 1.79 & 5.63 & 4.68 \\
\hline Proportion of total hopanoids (\%) & 0.33 & 2.82 & 9.31 & 21.94 & 0.23 & 0.71 & 2.25 & 3.93 \\
\hline Proportion of total steroids (\%) & 0.07 & 0.14 & 0.75 & 1.08 & 0.05 & 0.05 & 0.75 & 1.20 \\
\hline Proportion of total $n$-alkanes (\%) & 2.25 & 3.26 & 14.18 & 24.76 & 0.49 & 0.96 & 6.38 & 8.33 \\
\hline Proportion of total isoprenoids (\%) & 0.24 & 0.24 & 0.44 & 0.59 & 0.03 & 0.04 & 0.17 & 0.15 \\
\hline$D i /(D i+T r i)$ & 0.96 & 0.95 & 0.89 & 0.72 & 0.99 & 0.97 & 0.94 & 0.85 \\
\hline Sat $D i /$ Arom $D i$ & 23.64 & 23.44 & 14.15 & 6.09 & 39.93 & 9.56 & 12.20 & 4.66 \\
\hline Sat Tri/Arom Tri & 0.001 & 0.02 & 0.03 & 0.03 & 0.04 & 0.04 & 0.21 & 0.20 \\
\hline Sat Sesq/Arom Sesq & 3.05 & 1.12 & 4.33 & 3.62 & 6.46 & 1.34 & 8.34 & 2.58 \\
\hline Sat hopanoids/Arom hopanoids & 0.43 & 9.10 & 17.44 & 22.08 & 0.86 & 0.65 & 1.51 & 0.84 \\
\hline Sat steroids/Arom steroids & 0.73 & 0.45 & 2.20 & 2.89 & 1.71 & 1.55 & 5.19 & 13.50 \\
\hline Proportion of $\mathrm{Ol}$ in total Tri $(\%)$ & 38.44 & 52.25 & 53.79 & 65.55 & 48.50 & 51.97 & 60.94 & 62.00 \\
\hline Proportion of Urs in total Tri $(\%)$ & 16.88 & 10.44 & 11.71 & 8.67 & 15.66 & 19.48 & 8.15 & 10.52 \\
\hline Proportion of Lup in total Tri (\%) & 44.68 & 37.31 & 34.50 & 25.78 & 35.84 & 28.55 & 30.91 & 27.48 \\
\hline Ol/Lup & 0.86 & 1.40 & 1.56 & 2.54 & 1.35 & 1.82 & 1.97 & 2.26 \\
\hline Proportion of $n-\mathrm{C}_{14}-n-\mathrm{C}_{20}$ in total $n$-alkanes (\%) & 39.30 & 23.16 & 13.83 & 7.51 & 26.88 & 19.00 & 9.71 & 5.33 \\
\hline Proportion of $n-\mathrm{C}_{21}-n-\mathrm{C}_{25}$ in total $n$-alkanes (\%) & 19.45 & 17.70 & 15.68 & 19.12 & 23.67 & 14.09 & 15.46 & 13.64 \\
\hline Proportion of $n-\mathrm{C}_{26}-n-\mathrm{C}_{33}$ in total $n$-alkanes (\%) & 41.25 & 59.14 & 70.49 & 73.37 & 49.45 & 66.91 & 74.83 & 81.03 \\
\hline$C P I$ & 1.26 & 4.62 & 2.64 & 2.41 & 2.13 & 2.30 & 3.91 & 2.80 \\
\hline $\mathrm{Pr} / \mathrm{Ph}$ & 1.13 & 1.10 & 1.17 & 1.05 & 1.03 & 1.31 & 1.04 & 1.39 \\
\hline
\end{tabular}

Sat - Saturated; Arom — Aromatic; $\mathrm{Di}$ - Diterpenoids; Tri — Non-hopanoid triterpenoids; Sesq — Sesquiterpenoids; Ol — Oleanane derivatives; Urs — Ursane derivatives; Lup - Lupane derivatives; $C P I-$ Carbon Preference Index determined for distribution of $n$-alkanes $\mathrm{C}_{23}-\mathrm{C}_{33}, C P I=1 / 2 \quad\left[\Sigma\right.$ odd $\left(n-\mathrm{C}_{23}-n\right.$ - $\left.\mathrm{C}_{33}\right) /$ Eeven $\left(n-\mathrm{C}_{22}-n-\mathrm{C}_{32}\right)+\sum$ odd $\left(n-\mathrm{C}_{23}-n-\mathrm{C}_{33}\right) / \Sigma$ even $\left.\left(n-\mathrm{C}_{24}-n-\mathrm{C}_{34}\right)\right]$ (Bray \& Evans 1961); $P r-$ Pristane; $P h-$ Phytane.

quiterpenoids decreased in the following order: black SXC $>$ brown $\mathrm{SXC}>$ dark yellow $\mathrm{SXC}>$ pale yellow SXC. However, the proportion of these biomarkers was slightly higher in brown than in black SXC from both basins (Table 2).

The saturated fractions of all samples contain cubebane, dihydrovalencene and eudesmane, whereas sesquiterpenoid type constituents of aromatic fractions are calamenene, cuparene, curcumene, cadalene and isocadalene. Eudesmane predominates in distribution of saturated sesquiterpenoids, whereas cadalene is the most abundant aromatic sesquiterpenoid in all samples (Figs. 4-7). Sesquiterpenoid biomarkers are often not useful for a precise determination of the precursor plant community (van Aarssen et al. 1990; Otto et al. 1997; Otto \& Simoneit 2002), with the exception of cuparene. The presence of cuparene in all SXCs (Figs. 6, 7) clearly indicates a contribution of the conifer family Cupressaceae as a precursor of OM (Otto \& Wilde 2001; Haberer et al. 2006).

Diterpenoids and sesquiterpenoids are more abundant in the saturated than in the aromatic fraction (Table 2), indicating a relatively low degree of aromatization. Since almost all identified sesquiterpenoids (Figs. 4-7), as diterpenoids, originated from conifers, the similar behaviour of these classes of biomarkers regarding aromatization is understandable (Table 2). The highest degree of sesquiterpenoids aromatization is observed for dark yellow SXC and the lowest for brown SXC. 


\section{n-Alkanes and isoprenoids}

$n$-Alkanes are relatively abundant in the total ion current (TIC) of the saturated fraction in both basins (Figs. 4, 5; Table 2). $n$-Alkanes are identified in the range from $\mathrm{C}_{13}$ or $\mathrm{C}_{14}$ to $\mathrm{C}_{33}$ or $\mathrm{C}_{35}$. Absolute contents of $n$-alkanes do not show a clear relationship with SXCs. However, the proportion of $n$-alkanes in both basins clearly increased from pale and dark yellow to brown and black SXCs (Table 2).

The $n$-alkane patterns of all samples are dominated by odd long-chain homologues $\left(\mathrm{C}_{27}-\mathrm{C}_{31}\right)$ with a maximum at $n-\mathrm{C}_{29}$ (Figs. 4, 5), indicating a significant contribution of epicuticular waxes. Although samples showed generally similar distributions of $n$-alkanes, some differences in $n$-alkane patterns could be observed. The proportion of short-chain $n$-alkanes $\left(\mathrm{C}_{14}-\mathrm{C}_{20}\right)$ in both basins decreased in the order: pale yellow $\mathrm{SXC}>$ dark yellow $\mathrm{SXC}>$ brown $\mathrm{SXC}>$ black $\mathrm{SXC}$, associated with an increase in the proportion of long-chain homologues $\left(\mathrm{C}_{26}-\mathrm{C}_{33}\right)$ (Table 2). Since yellow SXCs contain a lower amount of liptinite macerals (see later Table 4), elevated content of short chain $n$-alkanes can be attributed to microbial degradation of long chain $n$-alkanes resulting in increasing content of lower $n$-alkane homologues (Faure et al. 1999; Marynowski \& Wyszomirski 2008; Marynowski et al. 2011). On the other hand, a higher proportion of short-chain $n$-alkanes in yellow SXCs could be related to direct impact of certain microbial communities since most of them are capable of synthesizing short-chain $n$-alkanes (Peters et al. 2005). The influence of different bacteria has already been supposed based on observed differences in the aromatization degree of di- and triterpenoids in different SXCs (Table 2). The proportion of middle chain $n$-alkanes $\left(\mathrm{C}_{21}-\mathrm{C}_{25}\right)$ which have numerous precursors such as vascular plants, microalgae, cyanobacteria, sphagnum and aquatic macrophytes (Ficken et al. 2000; Nott et al. 2000) was generally similar in all SXCs, showing slightly elevated value in pale yellow SXC from Kostolac (Table 2).

The values of the CPI (Carbon Preference Index; Bray \& Evans 1961), ranging from 1.26 to 4.62 (Table 2), are in accordance with terrestrial immature OM (Bechtel et al. 2002, 2007; Zdravkov et al. 2011, 2015). The lowest CPI in both basins is observed for pale yellow SXC (Table 2). This result could be attributed to the lower input of fatty acids from cuticular waxes, because these acids predominantly contain even numbers of carbon atoms in a molecule and after decarboxylation they produce odd-carbon-atom $n$-alkanes. The obtained result is consistent with the observation of Fabiańska \& Kurkiewicz (2013) who also reported lower CPI values in xylites with well preserved wood structure. However, the $C P I$ does not show any relationship with other studied sublithotypes.

Isoprenoids, pristane and phytane are identified in all samples in low amounts (Table 2). It is consistent with the observation that terrestrial immature OM usually contains very low concentrations of isoprenoids (Dzou et al. 1995; Hughes et al. 1995; Vu et al. 2009). Content of isoprenoids was the highest in yellow SXCs from Kolubara and pale yellow SXC from Kostolac (Table 2) in accordance with higher content of extractable OM (bitumen) in these samples (Table 1). However, the proportion of isoprenoids increased from yellow to brown and black SXCs (Table 2).

Taking into account the low abundance of pristane and phytane in the studied samples and possible differences in the precursors for acyclic isoprenoids (Goossens et al. 1984; Volkman \& Maxwell 1986; ten Haven et al. 1987), the pristane/phytane $(\mathrm{Pr} / \mathrm{Ph})$ ratio must be interpreted with care and it is usually omitted from interpretation of lignites. The investigated SXCs have generally similar values of $\mathrm{Pr} / \mathrm{Ph}$ ratio (1.03-1.39; Table 2), which are in the range reported for Middle and Upper Miocene lignites in Austria (Bechtel et al. 2007), Bulgaria (Zdravkov et al. 2011), Poland (Fabiańska \& Kurkiewicz 2013) and Turkey (Bechtel et al. 2014).

\section{Steroids and hopanoids}

Steroids were identified in the analysed samples in low amounts. The low content of steroids (Table 2) could be explained by the fact that the steroids mostly originate from higher plants, which contain very low amount of these biomarkers. The absolute content of steroids is higher in brown and black than in yellow SXCs and the relative proportions of these biomarkers follow the same trend (Table 2). Steroid biomarkers in the saturated fraction consist predominantly of $\mathrm{C}_{29} \Delta^{4}-, \Delta^{2}$ - and $\Delta^{5}$-sterenes, consistent with peat formation from terrigenous plants, whereas $\mathrm{C}_{27}$ and $\mathrm{C}_{28} \Delta^{4}-, \Delta^{2}$ - and $\Delta^{5}$-sterenes are identified in trace amounts in all samples. The single steroid compound detected in the aromatic fraction was 4-methyl, 24-ethyl, 19-norcholesta-1,3,5(10)-triene.

The ratio of saturated to aromatic steroids was $>1$ in all samples, with the exception of Kolubara pale and dark yellow SXCs, and showed the increasing trend from yellow to brown and black SXCs as it was observed for aromatization of non-hopanoid triterpenoids (Table 2).

All the samples from the Kolubara Basin, with exception of pale yellow SXC, have higher contents of hopanoids than samples from the Kostolac Basin (Table 2) indicating more intense microbial activity and peatification in a slightly more oxic environment, which is consistent with a lower amount of sulphur (Table 1). The content of hopanoids is similar in SXCs from the Kostolac Basin, whereas dark yellow and black SXCs from the Kolubara Basin are enriched in these biomarkers in comparison to pale yellow and brown SXCs. However, the proportion of hopanoids generally increased from pale yellow to black SXC (Table 2).

The hopane composition in the saturated fraction of all samples is characterized by the presence of $17 \alpha(\mathrm{H}) 21 \beta(\mathrm{H})$, $17 \beta(\mathrm{H}) 21 \alpha(\mathrm{H})$ and $17 \beta(\mathrm{H}) 21 \beta(\mathrm{H})$ compounds with $27-31$ carbon atoms, with the exception of $\mathrm{C}_{28}$ homologues. In all samples unsaturated $\mathrm{C}_{27}$ hop-17(21)-ene and $\mathrm{C}_{30}$ hop-17(21)-ene are also identified (Table 3 ). The aromatic hopanoids are represented by series of orphan aromatic hopanoids bearing an ethyl group at C-21. 
Table 3: Relative proportions (\%) of individual hopanoids calculated from mass chromatograms $m / z 191$.

\begin{tabular}{|c|c|c|c|c|c|c|c|c|}
\hline \multirow{2}{*}{$\begin{array}{l}\text { Basin } \\
\text { SXC }\end{array}$} & \multicolumn{4}{|c|}{ Kolubara } & \multicolumn{4}{|c|}{ Kostolac } \\
\hline & Pale yellow & Dark yellow & Brown & Black & Pale yellow & Dark yellow & Brown & Black \\
\hline $\mathrm{C}_{27}$ Hop-17(21)-ene & 15.29 & 1.37 & 0.53 & 0.93 & 18.38 & 32.78 & 10.49 & 6.44 \\
\hline $\mathrm{C}_{27} 17 \alpha(\mathrm{H})$-Hopane & 0.00 & 0.18 & 0.03 & 0.17 & 6.66 & 1.09 & 0.25 & 1.20 \\
\hline $\mathrm{C}_{27} 17 \beta(\mathrm{H})$-Hopane & 9.21 & 5.51 & 4.43 & 3.95 & 21.42 & 5.84 & 14.03 & 8.49 \\
\hline $\mathrm{C}_{29} 17 \alpha(\mathrm{H}) 21 \beta(\mathrm{H})$-Hopane & 7.71 & 1.41 & 1.82 & 1.81 & 13.08 & 2.44 & 7.40 & 3.21 \\
\hline $\mathrm{C}_{30}$ Hop-17(21)-ene & 12.04 & 2.00 & 2.99 & 3.15 & 6.56 & 2.33 & 1.59 & 4.61 \\
\hline $\mathrm{C}_{29} 17 \beta(\mathrm{H}) 21 \alpha(\mathrm{H})$-Hopane & 12.05 & 3.19 & 3.35 & 4.54 & 1.74 & 6.12 & 13.77 & 9.55 \\
\hline $\mathrm{C}_{30} 17 \alpha(\mathrm{H}) 21 \beta(\mathrm{H})$-Hopane & 4.68 & 1.15 & 0.69 & 0.82 & 5.13 & 1.76 & 0.50 & 0.82 \\
\hline $\mathrm{C}_{29} 17 \beta(\mathrm{H}) 21 \beta(\mathrm{H})$-Hopane & 2.29 & 0.30 & 0.71 & 0.86 & 0.41 & 0.47 & 5.64 & 0.36 \\
\hline $\mathrm{C}_{30} 17 \beta(\mathrm{H}) 21 \alpha(\mathrm{H})$-Hopane & 10.08 & 1.68 & 0.59 & 1.59 & 0.76 & 0.91 & 4.65 & 0.35 \\
\hline $\mathrm{C}_{31} 17 \alpha(\mathrm{H}) 21 \beta(\mathrm{H}) 22(\mathrm{R})$-Hopane & 6.81 & 74.56 & 77.02 & 73.63 & 17.45 & 35.68 & 24.66 & 51.32 \\
\hline $\mathrm{C}_{30} 17 \beta(\mathrm{H}) 21 \beta(\mathrm{H})$-Hopane & 7.74 & 2.15 & 1.40 & 1.20 & 7.02 & 3.45 & 2.45 & 3.20 \\
\hline $\mathrm{C}_{31} 17 \beta(\mathrm{H}) 21 \alpha(\mathrm{H})$-Hopane & 7.87 & 6.32 & 6.36 & 7.31 & 0.06 & 6.67 & 13.91 & 10.18 \\
\hline $\mathrm{C}_{31} 17 \beta(\mathrm{H}) 21 \beta(\mathrm{H})$-Hopane & 4.23 & 0.18 & 0.08 & 0.04 & 1.33 & 0.46 & 0.66 & 0.27 \\
\hline
\end{tabular}

The main precursors of hopanoids are prokaryotes, which were detected in much lower amounts in ferns, lichens, mosses and fungi. $\mathrm{C}_{31} 17 \alpha(\mathrm{H}) 21 \beta(\mathrm{H}) 22(\mathrm{R})-$ Hopane is the most abundant hopanoid in the saturated fraction of all studied samples, except the pale yellow SXC from Kostolac and Kolubara where $\mathrm{C}_{27} 17 \beta(\mathrm{H})$-22,29,30-trisnorhopane and $\mathrm{C}_{27}$ hop-17(21)-ene, respectively predominates hopane distribution (Table 3). Regarding hopane distribution, pale yellow SXC from both basins differs mostly from other samples by having the lowest proportion of $\mathrm{C}_{31} 17 \alpha(\mathrm{H}) 21 \beta(\mathrm{H}) 22(\mathrm{R})$-hopane and elevated proportions of $\mathrm{C}_{27}$ hop-17(21)-ene, $\mathrm{C}_{27} 17 \beta(\mathrm{H})$-22,29,30-trisnorhopane, $\mathrm{C}_{29} 17 \beta(\mathrm{H}) 21 \beta(\mathrm{H})-30$-norhopane; $\mathrm{C}_{30}$ hop-17(21)-ene, $\mathrm{C}_{30} 17 \alpha(\mathrm{H}) 21 \beta(\mathrm{H})$-hopane and $\mathrm{C}_{30} 17 \beta(\mathrm{H}) 21 \beta(\mathrm{H})$-hopane (Table 3 ). This result suggests a distinguished microbial community taking part in peatification of this SXC. The observed differences for pale yellow SXC, which were reflected through the highest content of bitumen (Table 1), highest proportion of short-chain $n$-alkanes and differences in aromatization degree of di- and triterpenoids (Table 2), can be partly related to differences in microbial communities.

Prominent $\mathrm{C}_{31} 17 \alpha(\mathrm{H}) 21 \beta(\mathrm{H}) 22(\mathrm{R})$-hopane is often reported in low rank coals (Stefanova et al. 2005b; Vu et al. 2009) and numerous precursors were proposed for this hopanoid biomarker (van Dorselaer et al. 1975; Killops et al. 1998; Thiel et al. 2003; Pancost et al. 2007). $\mathrm{C}_{27} 17 \beta(\mathrm{H})-$ and $\mathrm{C}_{29} 17 \beta(\mathrm{H}) 21 \beta(\mathrm{H})$-hopanes could originate from heterotrophic bacteria, chemoautotrophic bacteria and methanotrophic bacteria (Neunlist \& Rohmer 1985; Duan et al. 2004; Bechtel et al. 2014; Mitrović et al. 2016). In addition to chemoautotrophic bacteria and methanotrophic bacteria, cyanobacteria (Rohmer et al. 1984; Yamada et al. 1997), anaerobic, sulphate-reducing (Wolff et al. 1992) and ammonium oxidizing bacteria (Sinninghe Damsté et al. 2004), as well as some eukaryotic phyla (e.g., ferns, mosses; Bottari et al. 1972; Wakeham 1990) were proposed as possible sources of $\mathrm{C}_{30}$ hop-17(21)-ene. Therefore, the absence of a clear relationship between abundance of individual hopanoids and investigated SXCs (with the exception of pale yellow SXC) can be related to the mutual origin of individual hopanoids from different prokaryotes.
The ratio of saturated to aromatic hopanoids sharply increases from yellow to brown and black Kolubara SXCs, being $>1$ in all sublithotypes with the exception of pale yellow. On the other hand, in all Kostolac SXCs except brown SXC, aromatic hopanoids were somewhat more abundant than their saturated counterparts, resulting in a relatively uniform ratio of saturated to aromatic hopanoids in the range $0.65-0.86$ (Table 2). This result can be attributed to a higher content of saturated hopanoids in the Kolubara than in the Kostolac Basin.

\section{Maceral composition of SXCS}

The observed differences in biomarker distributions of SXCs, related to difference in sources and diagenetic alteration of $\mathrm{OM}$, are also reflected in petrographic characteristics.

\section{Maceral composition of SXCs from the Kolubara Basin}

Huminite macerals predominate in all SXCs from the Kolubara Basin (Fig. 8; Table 4). The content of total huminite macerals increased in order: black $\mathrm{SXC}<$ brown $\mathrm{SXC}<$ dark yellow $\mathrm{SXC}<$ pale yellow SXC, whereas lipitinite contents showed the opposite tend. Dark yellow, brown and black SXCs from the Kolubara Basin have relatively similar amounts of total inertinites, while pale yellow Kolubara SXC contained less of this maceral group. The content of total mineral matter showed the following trend: pale yellow $\mathrm{SXC}<$ dark yellow $\mathrm{SXC}<$ brown SXC $<$ black SXC. Pronounced differences were observed in the composition of huminite group macerals (Table 4). In yellow SXCs notable predominance of texitinite was observed, however this maceral was more abundant in pale yellow SXC. On the other hand ulminite prevailed among the huminite group macerals in brown and black SXC. As expected, densinite and attrinite were present in xylite-rich sublithotypes in a low amount. The contents of both macerals increased from yellow to brown and black SXC (Table 4). The content of gelinite was also very low, showing the increased trend from pale yellow to black SXC. Content of corpohuminite was the highest in dark yellow SXC and the lowest in brown SXC (Table 4). 

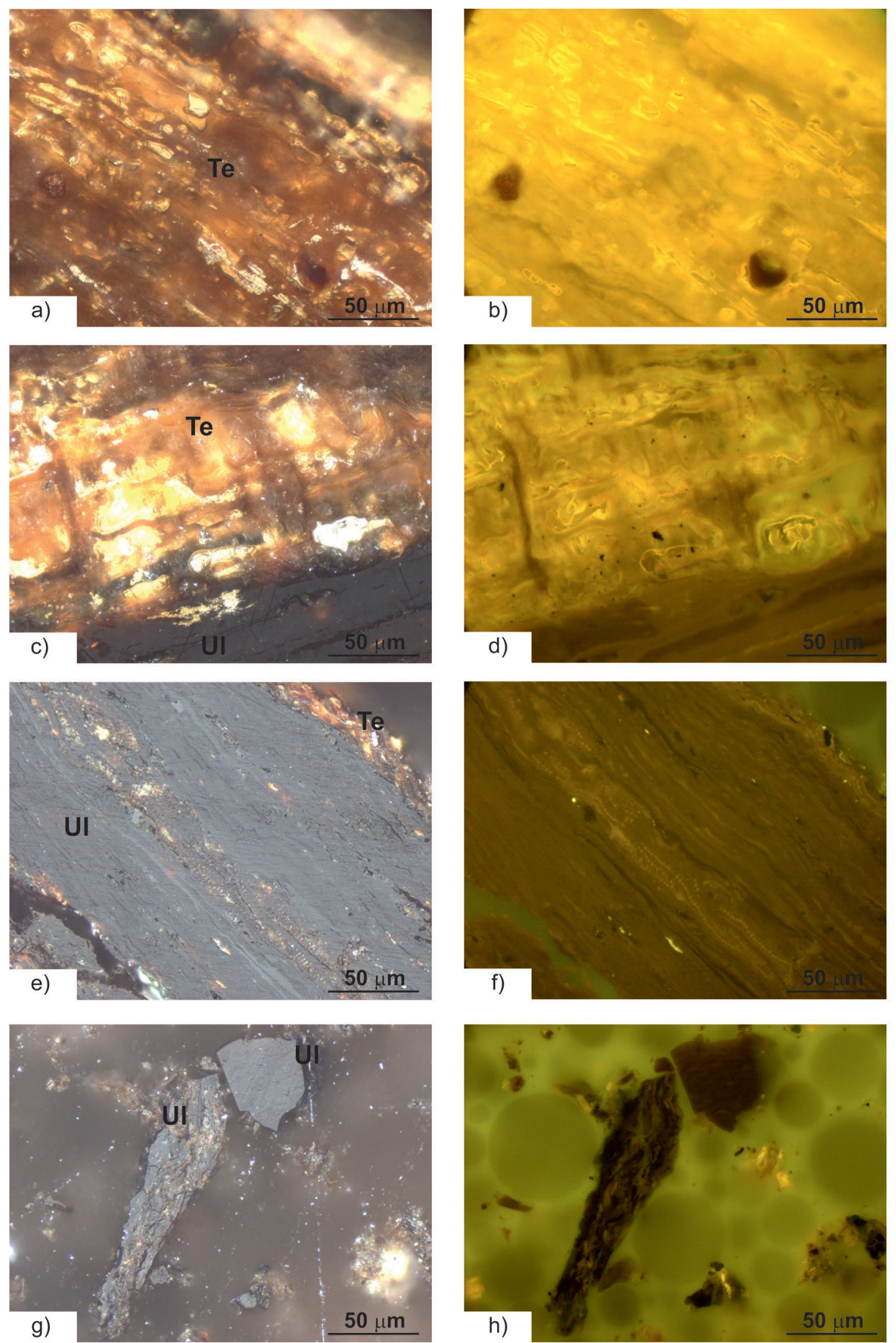

Fig. 8. Photomicrographs of typical macerals for pale yellow SXC (a-b); dark yellow SXC (c-d); brown SXC (e-f); black SXC (g-h) in normal light ( $\mathrm{a}, \mathrm{c}, \mathrm{e}, \mathrm{g})$ and UV light $(\mathrm{b}, \mathrm{d}, \mathrm{f}, \mathrm{h})$. Te - Textinite; Ul - Ulminite. 
Table 4: The maceral composition of SXCs based on mineral matter-free (vol. \%) and values of petrographic indices.

\begin{tabular}{|c|c|c|c|c|c|c|c|c|}
\hline \multirow{2}{*}{$\begin{array}{l}\text { Basin } \\
\text { SXC }\end{array}$} & \multicolumn{4}{|c|}{ Kolubara } & \multicolumn{4}{|c|}{ Kostolac } \\
\hline & Pale yellow & Dark yellow & Brown & Black & Pale yellow & Dark yellow & Brown & Black \\
\hline Textinite & 91.2 & 76.1 & 41.4 & 23.4 & 81.8 & 65.7 & 49.2 & 9.5 \\
\hline Ulminite & 0.8 & 6.8 & 42.0 & 48.5 & 5.4 & 19.3 & 33.3 & 64.4 \\
\hline Attrinite & 0.8 & 1.8 & 3.4 & 4.0 & 0.8 & 1.0 & 2.4 & 2.8 \\
\hline Densinite & 0.3 & 1.8 & 2.8 & 5.4 & 2.4 & 2.2 & 4.2 & 7.5 \\
\hline Gelinite & 0.3 & 0.8 & 1.8 & 3.4 & 0.8 & 1.0 & 1.2 & 1.2 \\
\hline Corpohuminite & 5.1 & 7.8 & 3.8 & 5.5 & 5.2 & 5.6 & 3.4 & 5.4 \\
\hline Total huminite & 98.6 & 95.1 & 95.1 & 90.2 & 96.4 & 94.9 & 93.6 & 90.7 \\
\hline Sporinite & 0.3 & 0.4 & 0.2 & 2.0 & 0.2 & 0.4 & 0.4 & 0.6 \\
\hline Cutinite & 0.0 & 0.0 & 0.2 & 0.4 & 0.0 & 0.0 & 0.0 & 0.0 \\
\hline Resinite & 0.3 & 0.4 & 0.2 & 0.4 & 2.4 & 1.6 & 0.4 & 0.4 \\
\hline Suberinite & 0.0 & 0.4 & 0.8 & 2.4 & 0.4 & 0.0 & 1.1 & 1.4 \\
\hline Liptodetrinite & 0.0 & 0.2 & 0.6 & 0.7 & 0.0 & 0.4 & 0.6 & 0.8 \\
\hline Total liptinite & 0.6 & 1.5 & 2.1 & 5.9 & 3.0 & 2.4 & 2.5 & 3.2 \\
\hline Fusinite & 0.0 & 0.6 & 1.0 & 0.4 & 0.0 & 0.2 & 0.8 & 0.4 \\
\hline Semifusinite & 0.3 & 1.1 & 0.4 & 0.4 & 0.0 & 0.6 & 0.8 & 0.4 \\
\hline Macrinite & 0.0 & 0.2 & 0.0 & 0.0 & 0.0 & 0.0 & 0.2 & 0.0 \\
\hline Funginite & 0.0 & 0.4 & 1.2 & 1.4 & 0.2 & 0.8 & 1.2 & 2.8 \\
\hline Inertodetrinite & 0.5 & 1.0 & 0.2 & 1.6 & 0.4 & 1.0 & 0.8 & 2.4 \\
\hline Total inertinite & 0.8 & 3.4 & 2.8 & 3.9 & 0.6 & 2.7 & 3.9 & 6.0 \\
\hline Mineral matter & 3.2 & 4.3 & 4.5 & 8.0 & 3.1 & 4.2 & 4.8 & 7.4 \\
\hline Textinite/Ulminite & 110.38 & 11.20 & 0.99 & 0.48 & 15.25 & 3.40 & 1.48 & 0.15 \\
\hline Resinite/Liptodetrinite & N.D. & 2.00 & 0.33 & 0.67 & N.D. & 3.75 & 0.67 & 0.57 \\
\hline Resinite/Suberinite & N.D. & 1.00 & 0.25 & 0.18 & 5.75 & N.D. & 0.40 & 0.31 \\
\hline TPI & 49.47 & 16.81 & 10.79 & 5.38 & 20.81 & 17.06 & 10.06 & 5.77 \\
\hline GI & 0.07 & 0.21 & 1.06 & 2.01 & 0.16 & 0.41 & 0.76 & 4.27 \\
\hline$\Sigma G($ vol. \%) & 6.13 & 14.41 & 35.58 & 45.03 & 11.17 & 21.09 & 29.64 & 54.70 \\
\hline
\end{tabular}

$T P I-$ Tissue Preservation Index $=($ Textinite + Ulminite + Corpohuminite + Fusinite $) /($ Attrinite + Densinite + Gelinite + Inertodetrinite $)($ Diessel 1986 , adopted by Kalkreuth et al. 1991 and Bechtel et al. 2003b); GI - Gelification Index $=($ Ulminite + Corpohuminite + Densinite + Gelinite $) /($ Textinite + Attrinite + Total inertinite $)($ Diessel 1986, adopted by Kalkreuth et al. 1991 and Bechtel et al. 2003b); $\Sigma G=$ Gelinite + Corpohuminite +0.67 (Ulminite+Densinite), mineral matter-free basis (Bielowicz 2013); N.D. - Not determined, due to the absence of liptodetrinite or sporinite.

Brown and black SXCs are characterized by predominance of suberinite among the liptinite maceral group (Table 4). In yellow SXCs resinite prevailed over liptodetrinite, while brown and black SXCs showed the opposite trend.

Black SXC is characterized by predominance of inertodetrinite and funginite among the inertinite group macerals (Table 4). In brown SXC the prevalence of funginite, followed by fusinite was observed. In pale yellow SXC, which generally contained a very low content of inertinites, inertodetrinite was the most abundant inertinite maceral.

\section{Maceral composition of SXCs from the Kostolac Basin}

Huminite macerals predominate in SXCs from the Kostolac Basin (Fig. 8; Table 4). The content of total huminite macerals increased in order: black SXC $<$ brown SXC $<$ dark yellow SXC $<$ pale yellow SXC. Xylite sublithotypes from the Kostolac Basin have uniform lipitinite contents, whereas inertinite content increased in order: pale yellow $<$ dark yellow $<$ brown $<$ black. The content of total mineral matter enlarged in the same order as inertines indicating partly allochthonous origin of inertinite macerals. Texitinite was predominant huminite maceral in yellow SXCs, whereas ulminite prevailed among the huminite group macerals in brown and particularly black SXC. The contents of densinite, attrinite and gelinite increased from yellow to brown and black SXC (Table 4). The content of corpohuminite is comparable in all SXCs from the Kostolac Basin with the exception of brown SXC, which has obviously a lower amount of this maceral (Table 4).

Resinite is the most abundant liptinite group maceral in yellow SXCs, while suberinite prevailed in brown and black SXCs. Inertodetrinite is the predominant inertinite maceral group in yellow SXCs, whereas brown and black SXCs are characterized by prevalence of funginite.

Comparison of maceral compositions of SXCs from the Kolubara and Kostolac Basin and their relationship with biomarker assemblages

Based on the data given in previous two chapters we can conclude that same individual SXCs (pale yellow, dark yellow, brown and black) from both basins generally have similar maceral composition among itself (Table 4).

The content of total huminites increased in the order: black SXC $<$ brown $\mathrm{SXC}<$ dark yellow $\mathrm{SXC}<$ pale yellow $\mathrm{SXC}$, whereas inertinite content showed the opposite trend in both basins. The content of total mineral matter increased in the following order: pale yellow $\mathrm{SXC}<$ dark yellow $\mathrm{SXC}<$ brown SXC $<$ black SXC in both basins, and amount of mineral matter was almost equal in the same individual SXCs (Table 4). 
This result suggests that clastic material is rather associated with black and brown than with yellow SXCs.

Regarding the composition of huminite group macerals, in accordance with the published data, SXCs differ by the textinite/ulminite ratio which sharply decreased in the order: pale yellow SXC $>$ dark yellow $\mathrm{SXC}>$ brown $\mathrm{SXC}>$ black $\mathrm{SXC}$ (Table 4). Textinite showed moderate positive correlation with content of total diterpenoids and triterpenoids with ursane and lupane skeleton, whereas ulminite negatively correlated with mentioned biomarkers (Table 5). The contents of densinite, attrinite and gelinite increased from yellow to brown and black SXC in both basins. Attrinite and gelinite showed negative correlation with the content of total diterpenoids, sesquiterpenoids and triterpenoids having ursane and lupane skeleton, whereas positive correlations were observed between these macerals and contents of $n$-alkanes (particularly, $\mathrm{C}_{26}-\mathrm{C}_{33}$ long-chain homologues) and hopanoids. The obtained result suggests a higher contribution of epicutilar waxes to brown and black SXCs and more intense gelification induced by microorganisms. The content of corpohuminite showed the same increasing trend in both basins: brown $\mathrm{SXC}<$ pale yellow $\mathrm{SXC}<$ black $\mathrm{SXC}<$ dark yellow $\mathrm{SXC}$. Corpohuminite positively correlated with triterpenoids, particularly those with oleanane skeleton, indicating a more pronounced contribution of certain angiosperm families to dark yellow SXC.

Although the content of total liptinites did not show a clear relationship with individual SXCs, probably due to the low content of this maceral group in all samples, some differences are observed in abundance of particular liptinite macerals. Brown and black SXCs are characterized by predominance of suberinite among the liptinite maceral group (Table 4). A typical feature of yellow SXCs is the prevalence of resinite over liptodetrinite, while brown and black SXCs showed the opposite trend in both basins. Consequently, regarding the composition of liptinite macerals, SXCs mostly differ according to resinite/liptodetrinite and resinite/suberinite ratios, which are higher in yellow than in brown and black SXCs (Table 4). Resinite showed significant positive correlation with content of diterpenoids and negative correlation with content of $n$-alkanes, particularly long-chain $n$-alkanes $\left(\mathrm{C}_{26}-\mathrm{C}_{33}\right)$, whereas liptodetrinite and suberinite showed the opposite correlations (Table 5). Therefore, it can be supposed that decrease of resinite/liptodetrinite and resinite/suberinite ratios reflect that change in colour from pale- and dark yellow to brown and black of SXC is followed by reduced contribution of conifer resinous material and increased impact of epicuticular waxes. A low contribution of epicuticular waxes to pale yellow SXC has already been assumed based on lower CPI values (Table 2).

No clear relationship between contents of individual inertinite macerals and sublithotypes was observed, with the exception of funginite the content of which increased in the order: pale yellow SXC $<$ dark yellow $\mathrm{SXC}<$ brown $\mathrm{SXC}<$ black SXC in both basins (Table 4 ). The absence of relationships between contents of individual inertinite macerals and xylite sublithotype could be attributed to heterogeneity (Borrego et al. 1997, 2000) and possible allochthonous origin of inertinite macerals (O'Keefe et al. 2013).

The change in colour of SXC from pale- and dark yellow to brown and black is followed by variations in the values of maceral indices, Tissue Preservation Index (TPI) and Gelification Index (GI) (Diessel 1986, adopted by Kalkreuth et al. 1991 and Bechtel et al. 2003b) (Table 4). TPI decreased in order pale yellow SXC $>$ dark yellow SXC $>$ brown SXC $>$ black SXC, while $G I$, as expected, showed the opposite trend in both basins (Table 4). Negative correlation between TPI and content of oleanane derivatives, accompanied by positive correlation between TPI and content of non-hopanoid triterpenoids with lupane skeleton (Table 5), indicates that greater tissue preservation in yellow than in brown and black SCXs, in part can be attributed to elevated content of Betulacea tissue which is characterized by relatively high tree density, being therefore resistant to degradation.

Table 5: Correlations between contents of selected macerals (based on mineral matter-free, vol. \%) and contents of biomarkers ( $\mu \mathrm{g} / \mathrm{g}$ TOC) according to Pearson test.

\begin{tabular}{|lrrrrrrrrr}
\hline $\mathbf{r}-$ Correlation coefficient & Tex. & Ulm. & Attr. & Gel. & Corpohum. & Res. & Sub. & Liptodetr. & TPI \\
\hline Total diterpenoids & 0.68 & -0.69 & -0.72 & -0.50 & 0.15 & 0.81 & -0.50 & -0.81 & 0.44 \\
Total non-hopanoid triterpenoids & 0.50 & -0.52 & -0.44 & -0.57 & 0.59 & -0.33 & -0.43 & -0.52 & 0.65 \\
Total sesquiterpenoids & 0.56 & -0.51 & -0.63 & -0.68 & -0.39 & 0.30 & -0.52 & -0.48 & 0.43 \\
Total steroids & -0.51 & 0.53 & 0.40 & 0.09 & -0.44 & -0.29 & 0.49 & 0.50 & -0.47 \\
Total hopanoids & -0.32 & 0.24 & 0.67 & 0.69 & 0.40 & -0.41 & 0.58 & 0.30 & -0.53 \\
Total $n$-alkanes & -0.11 & 0.08 & 0.53 & 0.39 & 0.03 & -0.74 & 0.45 & 0.11 \\
Total oleanane derivatives & 0.18 & -0.23 & -0.16 & -0.37 & 0.68 & -0.44 & -0.13 & -0.20 & -0.79 \\
Total ursane derivatives & 0.70 & -0.69 & -0.71 & -0.69 & 0.40 & -0.03 & -0.69 & -0.72 & 0.48 \\
Total lupane derivatives & 0.63 & -0.64 & -0.51 & -0.61 & 0.46 & -0.28 & -0.52 & -0.65 & 0.79 \\
$\mathrm{C}_{14}-\mathrm{C}_{20} n$-alkanes & 0.71 & -0.71 & -0.41 & -0.45 & 0.35 & -0.25 & -0.46 & -0.73 & 0.94 \\
$\mathrm{C}_{21}-\mathrm{C}_{25} n$-alkanes & 0.11 & -0.15 & 0.33 & 0.34 & 0.15 & -0.49 & 0.35 & -0.17 & 0.36 \\
$\mathrm{C}_{26}-\mathrm{C}_{33} n$-alkanes & -0.53 & 0.49 & 0.85 & 0.67 & -0.10 & -0.75 & 0.75 & 0.54 \\
\hline
\end{tabular}

Tex. — Textinite; Ulm. — Ulminite; Attr. — Attrinite; Gel. — Gelinite; Corpohum. — Corpohuminite; Res — Resinite; Sub. — Suberinite; Liptodetr. — Liptodetrinite; TPI - Tissue Preservation Index $=($ Textinite + Ulminite + Corpohuminite + Fusinite $) /($ Attrinite + Densinite + Gelinite + Inertodetrinite $)($ Diessel 1986 , adopted by Kalkreuth et al. 1991 and Bechtel et al. 2003b). The limiting value of $r$ for significance level ( $p$ ) of $95 \%$ is 0.70 (Davis 2002). 


\section{Conclusions}

The petrographic composition and biomarker assemblages of four SXCs (pale yellow, dark yellow, brown and black) originating from the most important lignite basins in Serbia were studied.

All the samples are dominated by diterpenoids, followed by non-hopanoid triterpenoids and $n$-alkanes. Other hydrocarbon constituents of bitumen are hopanoids, sesquiterpenoids, steroids and isoprenoids. The proportions of diterpenoids decrease in the following order: pale yellow SXC $>$ dark yellow SXC>brown SXC>black SXC, whereas proportions of all other biomarkers increase in the opposite trend, with the exception of sesquiterpenoids which showed slightly higher proportions in brown than in black SXC from both basins.

Distributions of biomarkers indicate that the contribution of arboreal vegetation vs. impact of herbaceous peat-forming plants decreased in the order: pale yellow $\mathrm{SXC}>$ dark yellow $\mathrm{SXC}>$ brown $\mathrm{SXC}>$ black $\mathrm{SXC}$, which resulted in reduction of tissue preservation. Conifers contributed significantly to the organic matter of all samples and predominated over angiosperms. Input of gymnosperm vs. angiosperm vegetation decreased from yellow to brown and black SXC. From the identified sesqui- and diterpenoids, a predominant role of the conifer families Cupressaceae, Taxodiaceae and Pinacea is concluded in all samples. Distribution of non-hopanoid triterpenoids indicates that the input of plants from the Betulacea family decreased from yellow to brown and black SXCs.

The ratio of short-chain $\left(\mathrm{C}_{14}-\mathrm{C}_{20}\right)$ to long-chain $\left(\mathrm{C}_{26}-\mathrm{C}_{33}\right)$ $n$-alkanes decreased in the order: pale yellow $\mathrm{SXC}>$ dark yellow SXC $>$ brown $\mathrm{SXC}>$ black SXC. In addition, pale yellow SXC from both basins showed the lowest Carbon Preference Index $(C P I)$ values. These results imply the lower input of fatty acids from epicuticular waxes, since these acids predominantly contain even numbers of carbon atoms in a molecule and by decarboxylation produce odd-carbon-atom $n$-alkanes. The lower contribution of epicuticular waxes to pale yellow SXC is also confirmed by the lowest content of liptinite macerals and total $n$-alkanes in this sublithotype.

Regarding hopanoid distribution, pale yellow SXC differs mostly from other SXCs having the lowest proportion of $\mathrm{C}_{31} 17 \alpha(\mathrm{H}) 21 \beta(\mathrm{H}) 22(\mathrm{R})$-hopane. Differences in hopane distribution, bitumen content, proportion of short-chain $n$-alkanes and degree of aromatization of di- and triterpenoids indicate that pale yellow SXC differs from other studied samples, mostly because of strong OM alteration caused by microbial communities.

The observed differences in precursor $\mathrm{OM}$ and diagenetic transformations are also reflected in petrographic characteristics. The content of total huminite macerals increases in the order: black $\mathrm{SXC}<$ brown $\mathrm{SXC}<$ dark yellow $\mathrm{SXC}<$ pale yellow SXC, whereas contents of total liptinite and inertinite macerals showed the opposite trend. The predominant huminite macerals in all SXCs are textinite or ulminite. SXCs differ according to the textinite/ulminite ratio which notably decreased in the order: pale yellow $>$ dark yellow $>$ brown $>$ black
Regarding the composition of liptinite macerals, the SXCs mostly differ according to resinite/liptodetrinite and resinite/ suberinite ratios, reflecting the contribution of well preserved woody material, including lignin tissue vs. the impact of epicuticular waxes. These ratios are higher in yellow than in brown and black SXC.

Acknowledgements: The study was financed by the Ministry of Education, Science and Technological Development of the Republic of Serbia (Projects 176006 and 451-03-01039/201509/05) and Österreichischer Austauschdienst (OeAD) (Project No. SRB 18/2016) which are gratefully acknowledged. We are also grateful to the anonymous reviewers.

\section{References}

Bechtel A., Sachsenhofer R.F., Gratzer R., Lücke A. \& Püttmann W. 2002: Parameters determining the carbon isotopic composition of coal and fossil wood in the Early Miocene Oberdorf lignite seam (Styrian Basin, Austria). Org. Geochem. 33, 8, 1001-1024.

Bechtel A., Gruber W., Sachsenhofer R.F., Gratzer R., Lücke A. \& Püttmann W. 2003a: Depositional environment of the Late Miocene Hausruck lignite (Alpine Foreland Basin): insights from petrography, organic geochemistry, and stable carbon isotopes. Int. J. Coal Geol. 53, 3, 153-180.

Bechtel A., Sachsenhofer R.F., Markic M., Gratzer R., Lücke A. \& Püttmann W. 2003b: Paleoenvironmental implications from biomarker and stable isotope investigations on the Pliocene Velenje lignite seam (Slovenia). Org. Geochem. 34, 9, $1277-1298$

Bechtel A., Reischenbacher A., Sachsenhofer R.F., Gratzer R., Lücke A. \& Püttmann W. 2007: Relations of petrographical and geochemical parameters in the middle Miocene Lavanttal lignite (Austria). Int. J. Coal Geol. 70, 4, 325-349.

Bechtel A., Karayiğit A.I., Sachsenhofer R.F., İnaner H., Christanis K. \& Gratzer R. 2014: Spatial and temporal variability in vegetation and coal facies as reflected by organic petrological and geochemical data in the Middle Miocene Çayirhan coal field (Turkey). Int. J. Coal Geol. 134-135, 46-60.

Bielowicz B. 2013: Petrographic composition of Polish lignite and its possible use in a fluidized bed gasification process. Int. J. Coal Geol. 116-117, 236-246.

Borrego A.G., Alvarez D. \& Menéndez R. 1997: Effects of Inertinite Content in Coal on Char Structure and Combustion. Energy Fuels 11, 3, 702-708.

Borrego A.G., Marbán G., Alonso M.J.G., Álvarez D. \& Menéndez R. 2000: Maceral Effects in the Determination of Proximate Volatiles in Coals. Energy Fuels 14, 1, 117-126.

Bottari F., Marsili A., Morelli I. \& Pacchiani M. 1972: Aliphatic and triterpenoid hydrocarbons from ferns. Phytochemistry 11, 8, 2519-2523.

Bray E.E. \& Evans E.D. 1961: Distribution of n-paraffins as a clue to recognition of source beds. Geochim. Cosmochim. Acta 22, 1, $2-15$.

Davis J. 2002: Statistics and Data Analysis in Geology, $3^{\text {rd }}$ Edition. John Wiley \& Sons, Inc. New York, 1-638.

Diessel C.F.K. 1986: On the correlation between coal facies and depositional environments. In: $20^{\text {th }}$ Newcastle Symposium on "Advances in the Study of the Sydney Basin": Publ., 246, Proc., 1986. Department of Geology, University of Newcastle, Australia, 19-22. 
Dimitrijević M.D. (Ed.) 2000: Geological Atlas of Serbia No-14. Metallogenic map and map of ore formations. Ministry of Mining and Energy, Republic of Serbia, Belgrade (in Serbian).

Duan Y., Wu B., Zheng G., Zhang H. \& Zheng C. 2004: The specific carbon isotopic compositions of branched and cyclic hydrocarbons from Fushun oil shale. Chin. Sci. Bull. 49, 4, 369-373.

Dzou L.I.P., Noble R.A. \& Senftle J.T. 1995: Maturation effects on absolute biomarker concentration in a suite of coals and associated vitrinite concentrates. Org. Geochem. 23, 7, 681-697.

Edress N. 2007: Coalification, Coal Facies and Depositional Environment of the $9^{\text {th }}$ to $12^{\text {th }}$ Coal Seams of the Jan Šverma Mine Group, Lampertice Member (Intra-Sudetic Basin, Czech Republic) from the View Point of Coal Petrology. ICCP News 41, 23-24.

Ercegovac M. 1989: Micropetrographic composition of coal from Stanari with special emphasis on the content of xylite and features of briquetting. Bulletin of Mines 28, 28-37 (in Serbian with English abstract).

Ercegovac M. \& Pulejković D. 1991: Petrographic Composition and Coalification Degree of Coal in the Kolubara Coal Basin. Annales Geol. de la penin. Balkanique 55, 2, 223-239.

Fabiańska M.J. \& Kurkiewicz S. 2013: Biomarkers, aromatic hydrocarbons and polar compounds in the Neogene lignites and gangue sediments of the Konin and Turoszów Brown Coal Basins (Poland). Int. J. Coal Geol. 107, 24-44.

Faure P., Landais P. \& Griffault L. 1999: Behavior of organic matter from Callovian shales during low-temperature air oxidation. Fuel 78, 13, 1515-1525.

Feller C., Brossard M., Chen Y., Landa E.R. \& Trichet J. 2010: Selected pioneering works on humus in soils and sediments during the 20th century: A retrospective look from the International Humic Substances Society view. Phys. Chem. Earth 35, 15-18, 903-912.

Ficken K.J., Li B., Swain D.L. \& Eglinton G. 2000: An n-alkane proxy for the sedimentary input of submerged/floating freshwater aquatic macrophytes. Org. Geochem. 31, 7-8, 745-749.

Goossens H., de Leeuw J.W., Schenck P.A. \& Brassell S.C. 1984: Tocopherols as likely precursors of pristane in ancient sediments and crude oils. Nature $312,440-442$.

Haberer M.R., Mangelsdorf K., Wilkes H. \& Horsfield B. 2006 : Occurrence and palaeoenvironmental significance of aromatic hydrocarbon biomarkers in Oligocene sediments from the Mallik 5L-38 Gas Hydrate Production Research Well (Canada). Org. Geochem. 37, 5, 519-538.

Hayek E.W.H., Jordis U., Moche W. \& Sauter F. 1989: A bicentennial of betulin. Phytochemistry 28, 9, 2229-2242.

Hughes W.B., Holba A.G. \& Dzou L.I.P. 1995: The ratios of dibenzothiophene to phenanthrene and pristane to phytane as indicators of depositional environment and lithology of petroleum source rocks. Geochim. Cosmochim. Acta 59, 17, 3581-3598.

International Committee for Coal Petrology (ICCP) 1993: http:// www.iccop.org/documents/1993-iccp-international-handbookof-coal-petrography-3rd-suppl-to-2nd-ed-pdf.pdf (last accessed November 28, 2017)

International Committee for Coal Petrology (ICCP) 2001: The new inertinite classification (ICCP System 1994). Fuel 80, 4, 459-471.

ISO 7404-3 2009: Methods for the Petrographic Analysis of Coals - Part 3: Method of Determining Maceral Group Composition. International Organization for Standardization, Geneva, Switzerland, 1-7.

Jacob H. 1961: Die Petrographische Bestimmung das Xylitgehaltes von Weichbraunkohlen. Geol. Jahrb. 79, 145-172.

Jelenković R., Kostić A., Životić D. \& Ercegovac M. 2008: Mineral resources of Serbia. Geol. Carpath. 59, 4, 345-361.
Kalkreuth W., Kotis T., Papanicolaou C. \& Kokkinakis P. 1991: The geology and coal petrology of a Miocene lignite profile at Meliadi Mine Katerini, Greece. Int. J. Coal Geol. 17, 1, $51-67$.

Kalkreuth W., Keuser C., Fowler M., Li M., McIntyre D., Püttmann W. \& Richardson R., 1998: The petrology, organic geochemistry and palynology of Tertiary age Eureka Sound Group coals, Arctic Canada. Org. Geochem. 29, 1-3, 799-809.

Kezović M. 2011: Coal bearing in Kolubara basin. The Journal of the Public Enterprise Electric Power Industry of Serbia 64, 154-163 (in Serbian with English abstract).

Killops S.D., Raine J.I., Woolhouse A.D. \& Weston R.J. 1995: Chemostratigraphic evidence of higher-plant evolution in the Taranaki Basin, New Zealand. Org. Geochem. 23, 5, 429-445.

Killops S.D., Funnell R.H., Suggate R.P., Sykes R., Peters K.E., Walters C.C., Woolhouse A.D., Weston R.J. \& Boudou J.-P. 1998: Predicting generation and expulsion of paraffinic oil from vitrinite-rich coals. Org. Geochem. 29, 1-3, 1-21.

Killops S., Cook R., Raine J., Weston R. \& Woolhouse T. 2003 A tentative New Zealand chemostratigraphy for the JurassicCretaceous based on terrestrial plant biomarkers. New Zealand J. Geol. Geophys. 46, 1, 63-77.

Kwiecińska B. \& Wagner M. 1997: Classification of Qualitative Features of Brown Coal from Polish Deposits according to Petrographical, Chemical and Technological Criteria. Wydawnictwo Centrum PPGSMiE PAN, Kraków, 1-87 (in Polish with English summary).

Markic M. \& Sachsenhofer R.F. 1997: Petrographic composition and depositional environments of the Pliocene Velenje lignite seam (Slovenia). Int. J. Coal Geol. 33, 3, 229-254.

Marynowski L. \& Wyszomirski P. 2008: Organic geochemical evidences of early diagenetic oxidation of the terrestrial organic matter during the Triassic arid and semi arid climatic conditions. Appl. Geochem. 23, 9, 2612-2618.

Marynowski L., Szełęg E., Jędrysek M.O. \& Simoneit B.R.T. 2011: Effects of weathering on organic matter: II. Fossil wood weathering and implications for organic geochemical and petrographic studies. Org. Geochem. 42, 9, 1076-1088.

Meyers P.A. \& Ishiwatari R. 1993: Lacustrine organic geochemistry an overview of indicators of organic matter sources and diageneses in lake sediments. Org. Geochem. 20, 7, 867-900.

Mitrović D., Đoković N., Životić D., Bechtel A, Šajnović A. \& Stojanović K. 2016: Petrographical and organic geochemical study of the Kovin lignite deposit, Serbia. Int. J. Coal Geol. 168, $80-107$.

Nakamura H., Sawada K. \& Takahashi M. 2010: Aliphatic and aromatic terpenoid biomarkers in Cretaceous and Paleogene angiosperm fossils from Japan. Org. Geochem. 41, 9, 975-980.

Neunlist S. \& Rohmer M. 1985: Novel hopanoids from the methylotrophic bacteria Methylococcus capsulatus and Methylomonas methanica. (22S)-35-aminobacteriohopane-30,31,32,33,34-pentol and (22S)-35-amino-3 3 -methylbacteriohopane-30,31,32,33,34pentol. Biochem. J. 231, 3, 635-639.

Nott C.J., Xie S., Avsejs L.A., Maddy D., Chambers F.M. \& Evershed R.P. 2000: n-Alkane distributions in ombrotrophic mires as indicators of vegetation change related to climate variation. Org. Geochem. 31, 2-3, 231-235.

O'Keefe J.M.K., Bechtel A., Christanis K., Dai S., Di Michele W.A., Eble C.F., Esterle J.S., Mastalerz M., Raymond A.L., Valentim B.V., Wagner N.J., Ward C.R. \& Hower J.C. 2013: On the fundamental difference between coal rank and coal type. Int. J. Coal Geol. 118, 58-87.

Otto A. \& Wilde V. 2001: Sesqui-, di-, and triterpenoids as chemosystematic markers in extant conifers - a review. Bot. Rev. 67, 2, $141-238$. 
Otto A. \& Simoneit B.R.T. 2002: Biomarkers of Holocene buried conifer logs from Bella Coola and North Vancouver, British Columbia, Canada. Org. Geochem. 33, 11, 1241-1251.

Otto A., Walther H. \& Püttmann W. 1997: Sesqui- and diterpenoid biomarkers preserved in Taxodium-rich Oligocene oxbow lake clays, Weisselster Basin, Germany. Org. Geochem. 26, 1-2, $105-115$.

Pancost R.D., Steart D.S., Handley L., Collinson M.E., Hooker J.J., Scott A.C., Grassineau N.V. \& Glasspool I.J. 2007: Increased terrestrial methane cycling at the Palaeocene-Eocene thermal maximum. Nature 449, 332-336.

Peters K.E., Walters C.C. \& Moldowan J.M. 2005: The Biomarker Guide Vol. 2: Biomarkers and Isotopes in the Petroleum Exploration and Earth History. Cambridge University Press, Cambridge, 475-1155.

Pickel W., Kus J., Flores D., Kalaitzidis S., Christanis K., Cardott B.J., Misz-Kennan M., Rodrigues S., Hentschel A., Hamor-Vido M., Crosdale P., Wagner N. 2017: Classification of liptinite ICCP System 1994. Int. J. Coal Geol. 169, 40-61.

Philp R.P. 1985: Fossil Fuel Biomarkers: Applications and Spectra. Methods in Geochemistry and Geophysics. Elsevier, Amsterdam, $1-294$.

Radke M., Willsch H. \& Welte D.H. 1980: Preparative hydrocarbon group type determination by automated medium pressure liquid chromatography. Anal. Chem. 52, 3, 406-411.

Regnery J., Püttmann W., Koutsodendris A., Mulch A. \& Pross J. 2013: Comparison of the paleoclimatic significance of higher land plant biomarker concentrations and pollen data: a case study of lake sediments from the Holsteinian interglacial. Org. Geochem. 61, 73-84.

Reichl C., Schatz M. \& Zsak G. 2016: World-Mining-Data, vol. 31, Minerals Production, Vienna, Federal Ministry of Science, Research and Economy, Vienna, 1-248.

Rohmer M., Bouvier-Nave P. \& Ourisson G. 1984: Distribution of hopanoid triterpenes in prokaryotes. J. Gen. Microbiol. 130, $1137-1150$.

Schmid S., Bernoulli D., Fugenschuh B., Matenco L., Schefer S. Schuster R., Tischler M. \& Ustaszewski K. 2008: The AlpineCarpathian-Dinaridic orogenic system: correlation and evolution of tectonic units. Swiss J. Geosci. 101, 139-183.

Sinninghe Damsté J.S., Rijpstra W.I.C., Schouten S., Fuerst J.A., Jetten M.S.M. \& Strous M. 2004. The occurrence of hopanoids in planctomycetes: Implications for the sedimentary biomarker record. Org. Geochem. 35, 5, 561-566.

Stefanova M, Markova K., Marinov S. \& Simoneit, B.R.T. 2005a: Biomarkers in the fossils from the Miocene-aged Chukurovo lignite, Bulgaria: sesqui- and diterpenoids. Bull. Geosci. 80, 1, 93-97.

Stefanova M., Markova K., Marinov S. \& Simoneit B. R.T. 2005b: Molecular indicators for coal-forming vegetation of the Miocene Chukurovo lignite, Bulgaria. Fuel 84, 14-15, 1830-1838.

Stojanović K., Životić D., Šajnović A., Cvetković O., Nytoft H.P. \& Scheeder G. 2012: Drmno lignite field (Kostolac Basin, Serbia): origin and palaeoenvironmental implications from petrological and organic geochemical studies. J. Serb. Chem. Soc. 77, 8, 1109-1127.

Stout S. 1992: Aliphatic and aromatic triterpenoid hydrocarbons in a Tertiary angiospermous lignite. Org. Geochem. 18, 1, 51-66.
Suárez-Ruiz I., Flores D., Mendonça Filho J.G. \& Hackley P.C. 2012: Review and update of the applications of organic petrology: Part 1, geological applications. Int. J. Coal Geol. 99, 54-112.

Sykorova I., Pickel W., Christanis K., Wolf M., Taylor G.H. \& Flores, D. 2005: Classification of huminite-ICCP System 1994. Int. J. Coal Geol. 62, 1-2, 85-106.

Taylor G.H., Teichmüller M., Davis A., Diessel C.F.K., Littke R. \& Robert P. 1998: Organic Petrology. Gebrüder Borntraeger, Berlin, 1-704.

ten Haven H.L., de Leeuw J.W., Rullkötter J. \& Sinninghe Damsté J.S. 1987: Restricted utility of the pristane/phytane ratio as a palaeoenvironmental indicator. Nature 330, 641-643.

Thiel V., Blumenberg M., Pape T., Seifert R. \& Michaelis W. 2003: Unexpected occurrence of hopanoids at gas seeps in the Black Sea. Org. Geochem. 34, 1, 81-87.

van Aarssen B.G.K., Cox H.C., Hoogendoorn P. \& de Leeuw J.W. 1990: A cadinene biopolymer in fossil and extant dammar resins as a source for cadinanes and bicadinanes in crude oils from South East Asia. Geochim. Cosmochim. Acta 54, 11, 3021-3031.

van Dorselaer A., Albrecht P. \& Connan J. 1975: Changes in composition of polycyclic alkanes by thermal maturation (Yallourn Lignite, Australia). In: Campus R. \& Goñi J. (Eds.): Advances in Organic Geochemistry. Enadimsa, Madrid, 53-59.

Volkman J.K. \& Maxwell J.R. 1986: Acyclic isoprenoids as biological markers. In: Johns, R.B. (Ed.): Biological Markers in the Sedimentary Record. Elsevier, Amsterdam, 1-42.

Vu T.T.A., Zink K.-G., Mangelsdorf K., Sykes R., Wilkes H. \& Horsfield B. 2009: Changes in bulk properties and molecular compositions within New Zealand Coal Band solvent extracts from early diagenetic to catagenetic maturity levels. Org. Geochem. 40, 9, 963-977.

Wakeham S.G. 1990: Algal and bacterial hydrocarbons in particulate material and interfacial sediment of the Cariaco Trench. Geochim. Cosmochim. Acta 54, 5, 1325-1336.

Wakeham S.G., Schaffner C., \& Giger W. 1980: Polycyclic aromatic hydrocarbons in Recent lake sediments. II. Compounds derived from biological precursors during early diagenesis. Geochim. Cosmochim. Acta 44, 3, 415-429.

Wolff G.A., Ruskin N. \& Marshall J.D. 1992: Biogeochemistry of an early diagenetic concretion from the Birchi Bed (L. Lias, W. Dorset, U.K.). Org. Geochem. 19, 4-6, 431-444.

Yamada K., Ishiwatari R., Matsumoto K. \& Naraoka H. 1997: $\delta^{13} \mathrm{C}$ Records of diploptene in the Japan Sea sediments over the past 25 kyr. Geochem. J. 31, 5, 315-321.

Zdravkov A., Bechtel A., Sachsenhofer R.F., Kortenski J. \& Gratzer R. 2011: Vegetation differences and diagenetic changes between two Bulgarian lignite deposits - insights from coal petrology and biomarker composition. Org. Geochem. 42, 3, 237-254.

Zdravkov A., Bechtel A., Ćorić S. \& Sachsenhofer R.F. 2015: Depositional environment, organic matter characterization and hydrocarbon potential of Middle Miocene sediments from northeastern Bulgaria (Varna-Balchik Depression). Geol. Carpath. $66,5,409-426$.

Životić D., Bechtel A., Sachsenhofer R., Gratzer R., Radić D., Obradović M. \& Stojanović K. 2014: Petrological and organic geochemical properties of lignite from the Kolubara and Kostolac basins, Serbia: Implication on Grindability Index. Int. J. Coal Geol. 131, 344-362. 


\section{Appendix}

Table I: The list of compounds identified in the saturated and aromatic fractions of the analysed SXCs (Figs. 4-7).

\begin{tabular}{|c|c|c|}
\hline Compound & Molecular mass & Base peak(s) in the mass spectrum \\
\hline \multicolumn{3}{|l|}{ Saturated fraction } \\
\hline Cubebane & 206 & 163 \\
\hline Dihydrovalencene & 206 & 93 \\
\hline Eudesmane & 208 & 109 \\
\hline Isopimaradiene & 272 & 257 \\
\hline Isonorpimarane & 262 & 123,109 \\
\hline Norpimarane & 262 & 233 \\
\hline Dihydrorimuene & 274 & 259,149 \\
\hline Isophyllocladene & 272 & 120 \\
\hline Pimarane & 276 & $247,163,123,191$ \\
\hline $16 \beta(\mathrm{H})$-Phyllocladane & 274 & 123 \\
\hline $16 \alpha(\mathrm{H})$-Phyllocladane & 274 & 123 \\
\hline Des-A-olean-13(18)-ene & 328 & 189, 204, 313, \\
\hline Des-A-olean-12-ene & 328 & $203,218,189$, \\
\hline Des-A-lupane & 330 & $163,149,191$ \\
\hline $\mathrm{C}_{30}$ Hop-17(21)-ene & 410 & 367,231 \\
\hline $\mathrm{C}_{31} 17 \alpha(\mathrm{H}) 21 \beta(\mathrm{H})$-hopane & 426 & 191 \\
\hline $\mathrm{C}_{31} 17 \beta(\mathrm{H}) 21 \beta(\mathrm{H})$-hopane & 426 & 205,191 \\
\hline \multicolumn{3}{|l|}{ Aromatic fraction } \\
\hline Dihydro-ar-curcumene & 204 & 119 \\
\hline Cuparene & 202 & 132 \\
\hline Calamenene & 202 & 159 \\
\hline Curcumene & 204 & 119 \\
\hline Cadalene & 198 & 183 \\
\hline Isocadalene & 198 & 183 \\
\hline Phenanthrene & 178 & 178 \\
\hline 19-Norabieta-6,8,11,13-tetraene & 254 & 239 \\
\hline Hibaene & 272 & 134 \\
\hline 18-Norabieta-6,8,11,13-tetraene & 254 & 239 \\
\hline 18-Norabieta-8,11,13-triene & 256 & 241,159 \\
\hline Dehydroabietane & 270 & 255 \\
\hline Pyrene & 202 & 202 \\
\hline Simonellite & 252 & 237 \\
\hline Totarane & 252 & $237,195,179$ \\
\hline Sempervirane & 252 & $237,193,179,207$ \\
\hline Retene & 234 & 219 \\
\hline 2-Methylretene & 248 & 234 \\
\hline 3,4,7,12a-Tetramethyl-1,2,3,4,4a,11,12,12a-octahydrochrysene & 292 & 207 \\
\hline 3,4,7-Trimethyl-1,2,3,4-tetrahydrochrysene & 274 & 259 \\
\hline Perylene & 252 & 252 \\
\hline 24,25-Dinoroleana-1,3,5(10),12-tetraene & 376 & 145,158 \\
\hline 24,25-Dinorursa-1,3,5(10),12-tetraene & 376 & 145 \\
\hline 24,25-Dinorlupa-1,3,5(10)-triene & 378 & 145 \\
\hline D-ring monoaromatic hopane & 364 & 211 \\
\hline 1,2,4a,9-Tetramethyl-1,2,3,4,4a,5,6,14b-octahydropicene & 342 & 257 \\
\hline 4-Methyl, 24-ethyl, 19-norcholesta-1,3,5(10)-triene & 394 & 211 \\
\hline 7-Methyl, 3’-ethyl, 1,2-cyclopentanochrysene & 310 & 281 \\
\hline 1,2,9-Trimethyl-1,2,3,4-tetrahydropicene & 324 & 324,309 \\
\hline 2,2,9-Trimethyl-1,2,3,4-tetrahydropicene & 324 & 324,268 \\
\hline
\end{tabular}

